\title{
Investigating the Impact of Conformity and Obedience Pressures on Financial Managers' Unethical Decision Making with Emphasis on the Moderating Role of Individual Characteristics
}

\author{
Abbas Rezalouei \\ Ph.D. student in Accounting, Shiraz University, Shiraz, Iran \\ Rezaloie@yahoo.com \\ Gholamhossein Mahdavi * \\ Professor of Accounting, Shiraz University, Shiraz, Iran \\ (corresponding author) Ghmahdavi@ rose.shirazu.ac.ir
}

\begin{abstract}
:
Professions are defined and judged by the knowledge, skills, attitudes, behaviors and ethics of their members. The occurrence of numerous financial scandals in which accountants played an indispensable role, showed that the role of psychological, personality, and environmental factors in ethical decision-making needs to be given more attention. The present study investigates the role of conformity and obedience pressure in the ethical decision-making process as well as the moderating role of power distance orientation, professional commitment, and organizational commitment. The statistical population of the study includes financial managers of active companies in Lakan industrial Estate of Rasht city, with an estimated 140 company. Using the Cochran's formula, the number of samples was determined to be 103. Required data were collected in 2019 with the scenario and questionnaire. The method of data analysis is one-way analysis of variance and mixed variance analysis via SPSS. Findings show the impact of conformity and obedience pressure on the likelihood of making unethical decisions. The moderating effect of professional commitment and power distance orientation on the relationship between obedience pressure and unethical decision making was also confirmed. However, there was no evidence of the moderating effect of organizational commitment. Given that the results confirm the role of ethical pressure in increasing the likelihhod of unethical decisions by accountants and reducing the quality of financial reporting, therefore, it is necessary to pay more attention to this issue in formulating regulatory rules, such as corporate governance.
\end{abstract}

Keywords: Unethical Decision Making, Ethical Pressures, Obedience Pressure, Conformity Pressure.

\section{Copyrights (c) (1)(2)}

This license only allowing others to download your works and share them with others as long as they credit you, but they can't change them in any way or use them commercial. 


\section{مقاله يخوهشى}

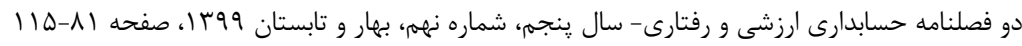

\section{بررسى تأثير فشار هاى همنوايى و فرمانبردارى بر تصميم فير اخلاقى مديران مالى با تأكيد برنقش تعديل كنندىى ويز تىهاى فردى \\ غالامحسين مهدوى \\ تاريخ يذيرش: V•/\% \\ عباس رضالوئى \\ تاريخ دريافت:99/1V}

جـكيuه

حرفهها با دانش، مهارت، نخرش، رفتار و اخلاق افراد آن حرفه تعريف و ق ضاوت مى شوند. وقوع موارد متعدد رسوايىهاى مالى، كه حسابداران نقش غيرقابل جشميوشى در آن ايفا كردند،

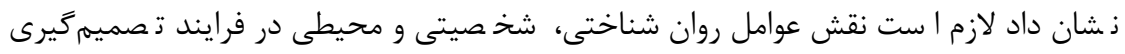

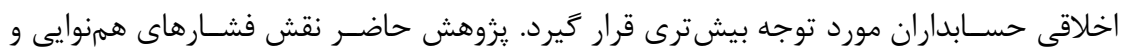

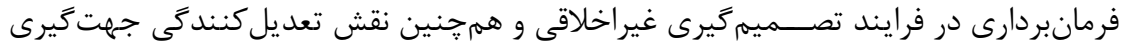

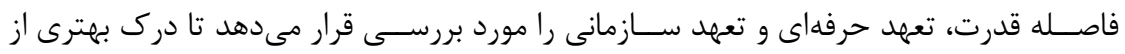

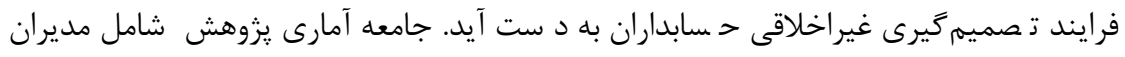

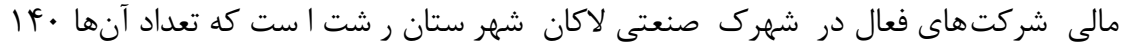

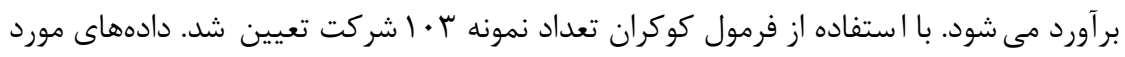

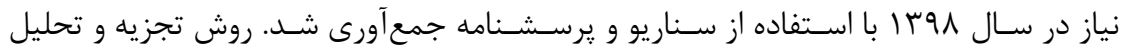
دادهها تجزيه و تحليل واريانس يك طرفه و تجزيه و تحليل واريانس تركيبى است كه با استفاده

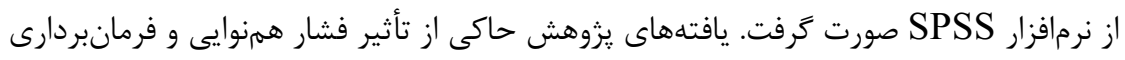

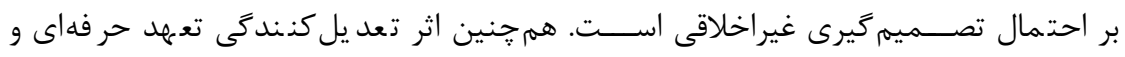
جهت گيرى فاصله قدرت بر رابطه فشار فرمانبردارى با تصميمَّيرى غيراخلاقى مورد تأييد قرار گرفت. با اينحال شواهدى در خصوص اثر تعديل كنندگى تعهد سازمانى مشاهده نشد. با توجه به اين كه نتايج مويد نقش فشار اخلاقى در افزايش احتمال تصميمثيرى غيراخلاقى حسابداران

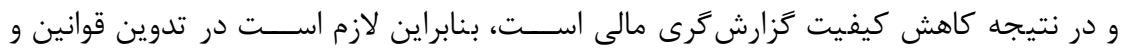
مقررات نظارتى مانند نظام راهبرى شركتى به اين موضوع بيش از ييش توجه شود.

$$
\text { وازًَان كليدى: تصميمَيرى غيراخلاقى، فشار اخلاقى ، فشار فرمانبردارى، فشار همنوايى. }
$$

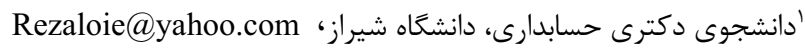

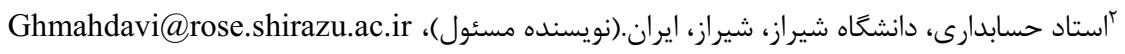




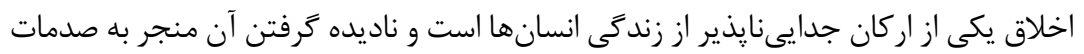

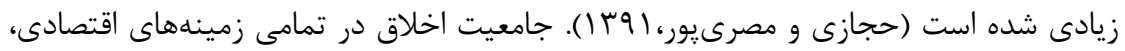

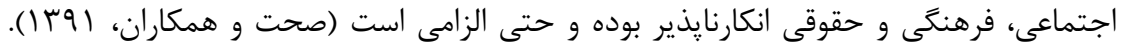

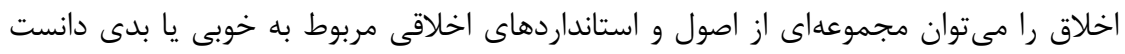

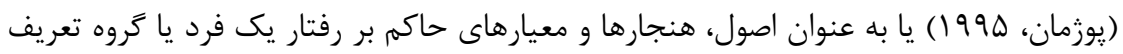

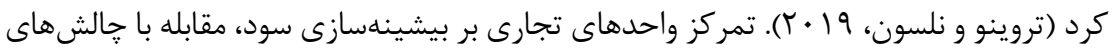

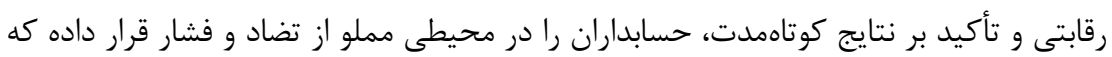

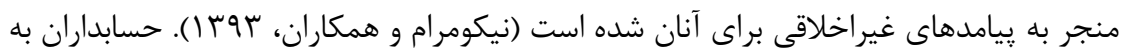

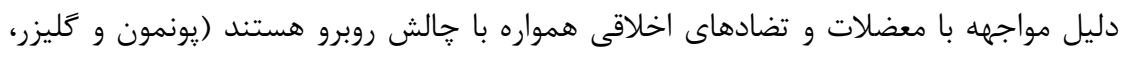

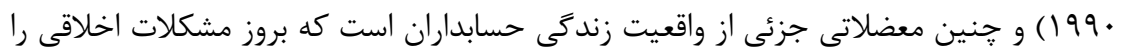

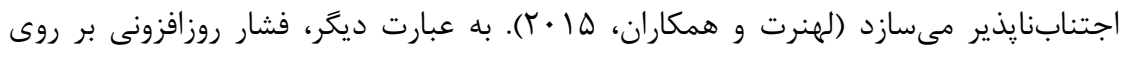

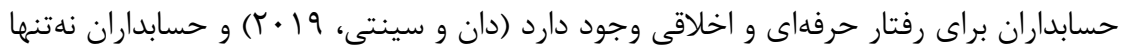
بايد واجد شرايط و صلاحيت حرفهاى باشند، بلكه بايد از درجه بالايى از صداقت و درستكارى

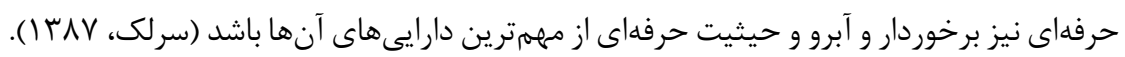

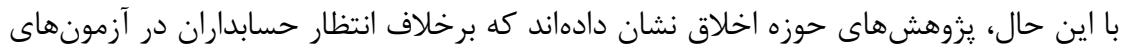

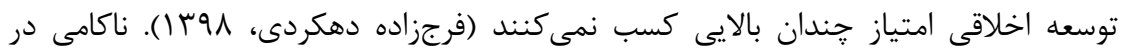

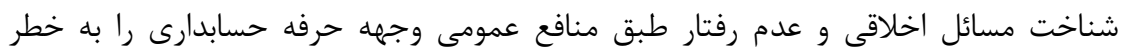

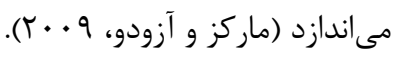

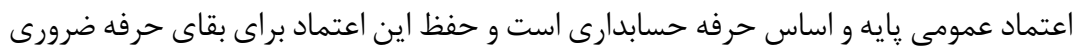

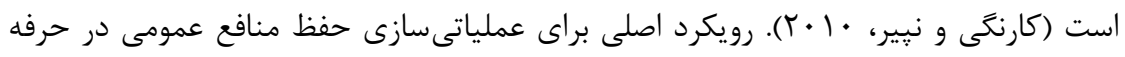

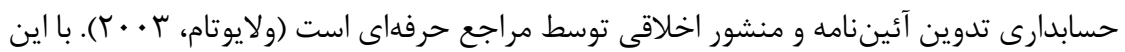
حال، وقوع موارد عديده رسوايىهاى مالى نشان داد كه منشورهاى اخلاقى به تنهايى براى تراى تانى

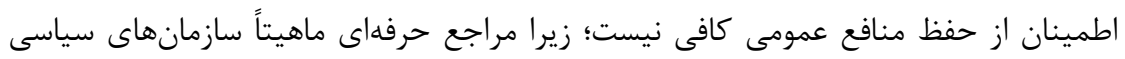

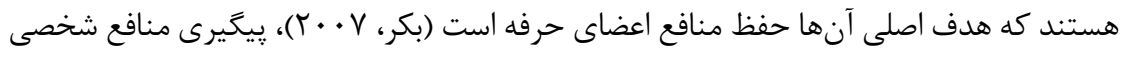

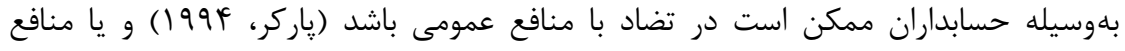

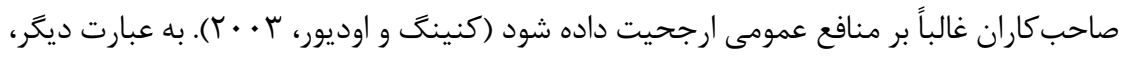

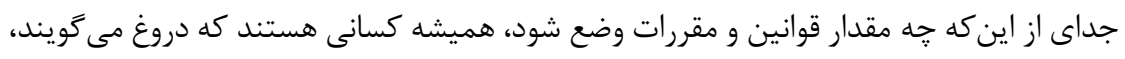

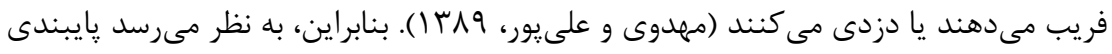

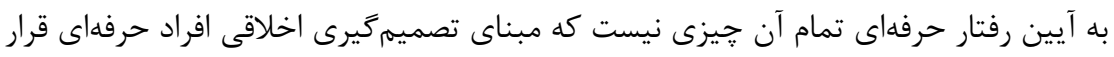




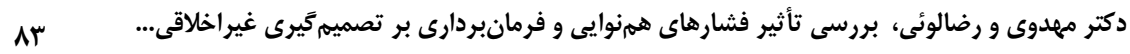

مى گيرد و تنزل اخلاق كه يكى از عوامل اصلى موثر در رخداد رسوايىهاى مالى است لازم است

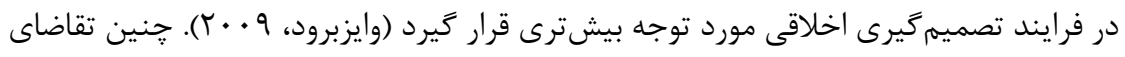

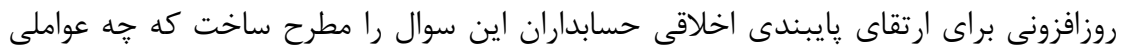

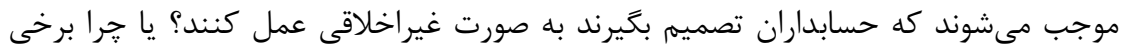

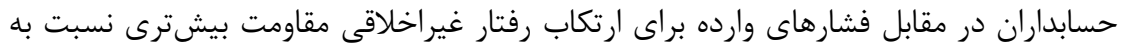

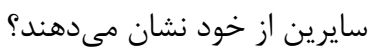
مولفههايى شامل نفع شخصى، ناتوانى در حفظ استقلال، ضعف رهبرى، فرهنَ سازمانى

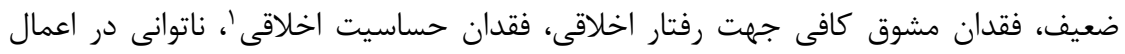

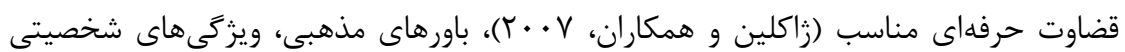

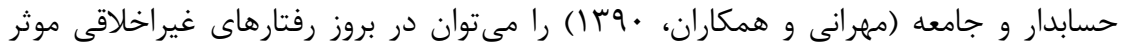

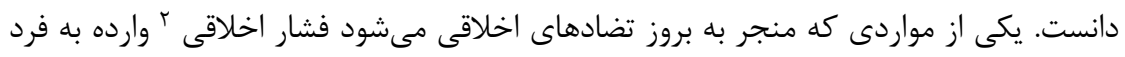

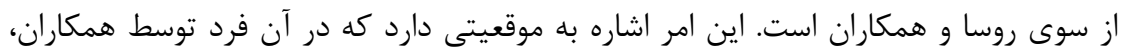

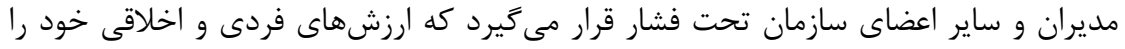

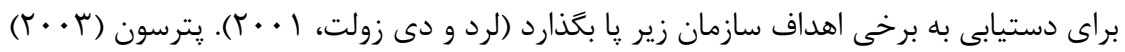

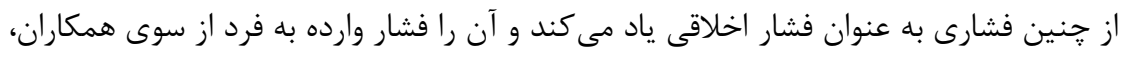

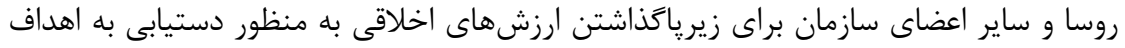

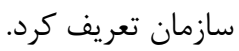

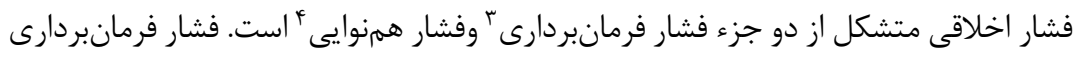
ناشى از انتظار تبعيت از دستورهاى مقامات صاحب قدرت است. در حالى كه فشارهمنوايى مربوط

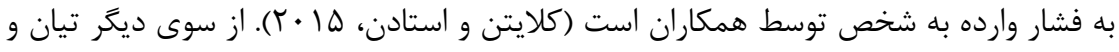

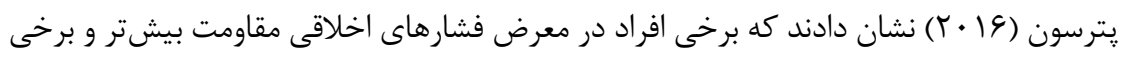

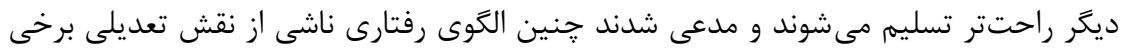

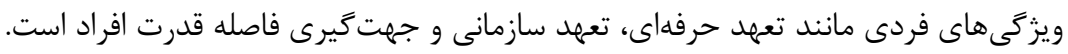

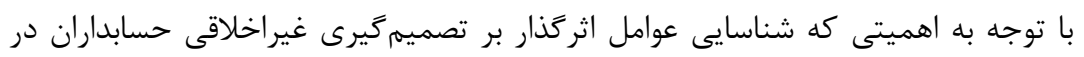

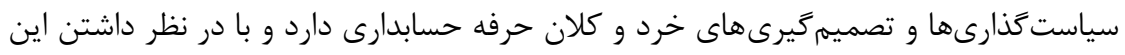

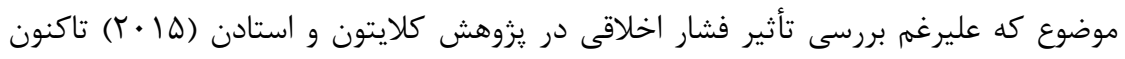

${ }^{1}$ Ethical Sensitivity

${ }^{2}$ Ethical Pressure

${ }^{3}$ Obedience Pressure

${ }^{4}$ Conformity Pressure 
يزوهشى در ايران انجام نشده است كه تأثير فشار اخلاقى بر تصميم كيرى غيراخلاقى حسابداران

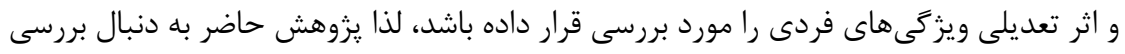

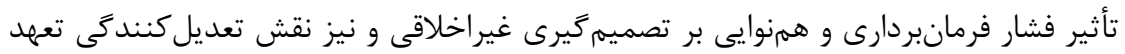

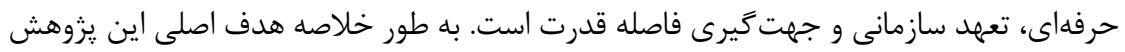

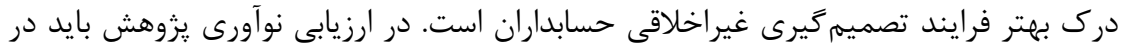

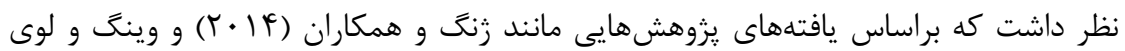

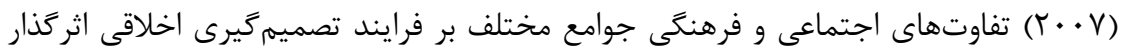

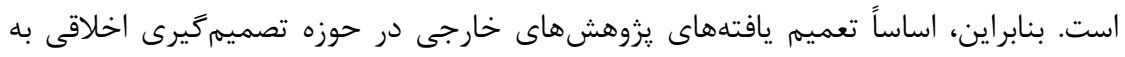

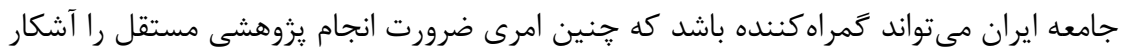

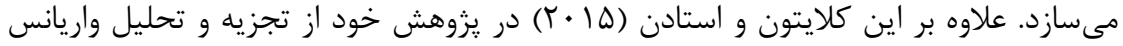

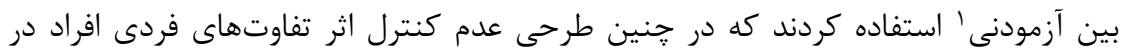

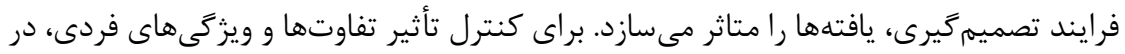

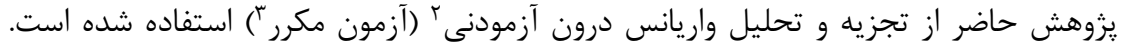

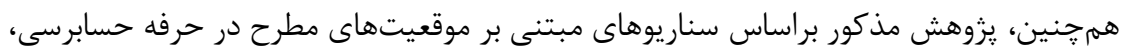

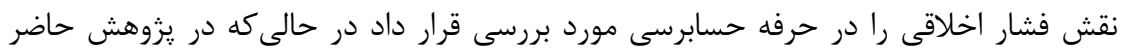

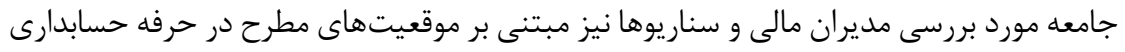

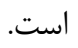

\section{r- مبانى نظرى و پييشينه يزوهش}

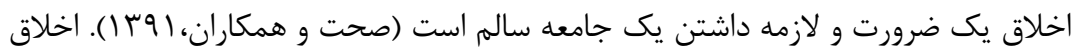

راهنماى افراد در تشخيص خوب از بد، درست از نادرست، منصفانه از غيرمنصفانه و تصميمَّيرى

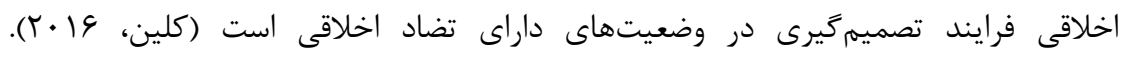

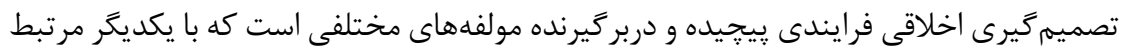

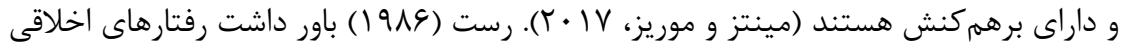
نتيجه يك فرآيند تصميمَيرى واحد و يكسان نيستند بلكه حاصل تركيبى از ساختارهاى

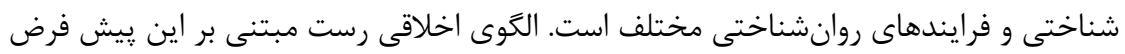

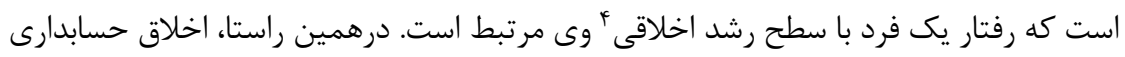

${ }^{1}$ Between Subject ANOVA

${ }^{2}$ Within Subject ANOVA

${ }^{3}$ Repeated Measure

${ }^{4}$ Moral Development 
به عنوان حوزهاى از اخلاق كاربردى' و جزئى از اخلاق تجارت` مطرح است كه از قواعد، اصول و

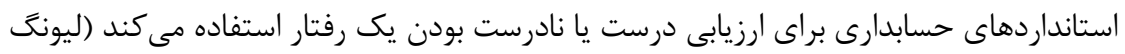

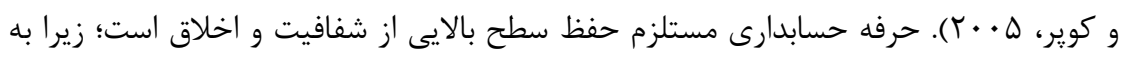

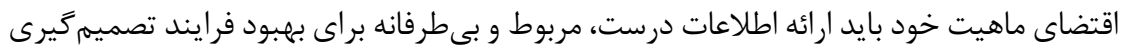

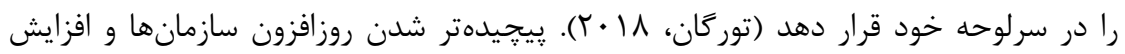

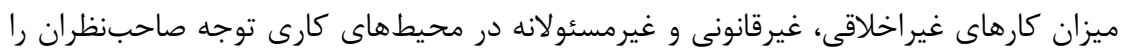

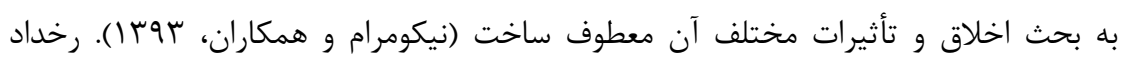

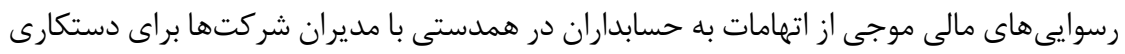

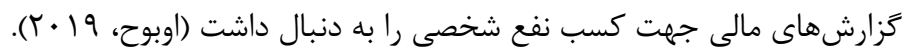

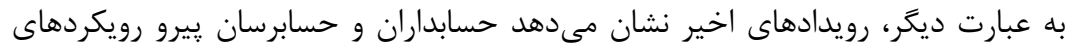

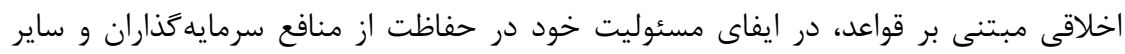

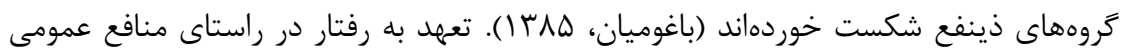

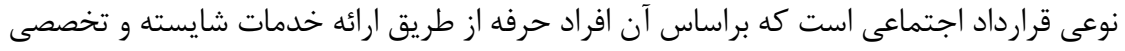

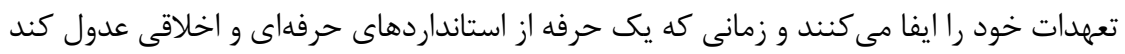

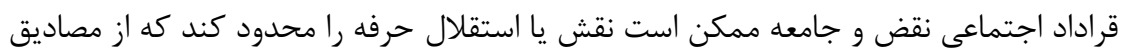

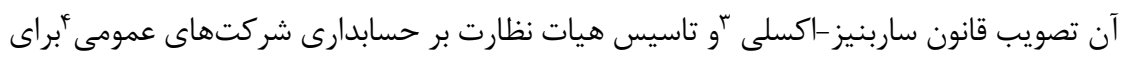

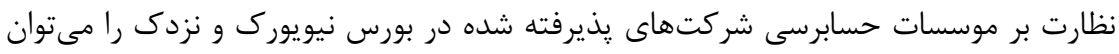

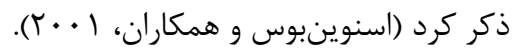

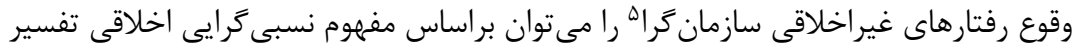

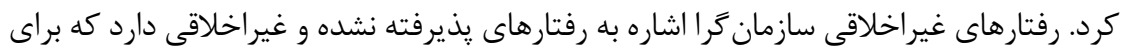

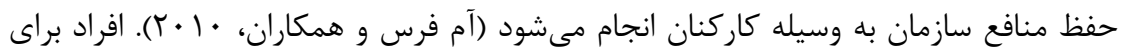

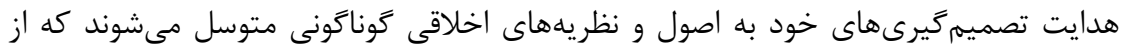

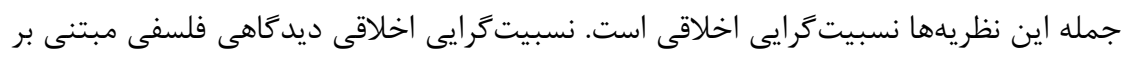

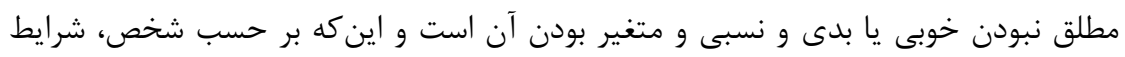

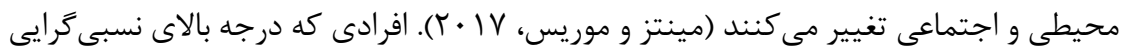

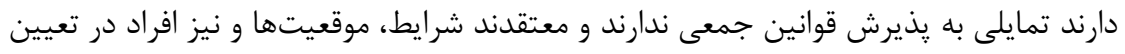

\footnotetext{
${ }^{1}$ Applied Ethics

${ }^{2}$ Business Ethics

${ }^{3}$ Sarbanes-Oxley Act

${ }^{4}$ Public Company Accounting Oversight Board (PCAOB)

${ }^{5}$ Unethical Pro-Organizational Behavior
} 
اخلاقى بودن و غيراخلاقى بودن يك تصميم دخيل هستند (اعتمادى و ديانتى، MM I I). يذيرش

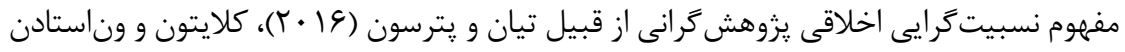

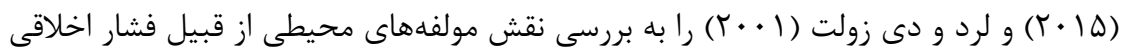

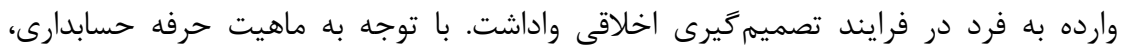

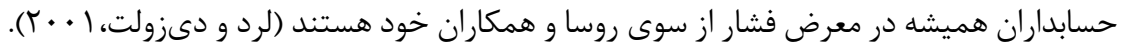
جنين فشارهايى به وضوح در حوزه كارى حسابداران قابل مشاهده است. بيش از هـ دم درصد حسابداران فشار براى عدول از استانداردهاى اخلاقى را گزارش كردهانداند (حسابداران مديريت

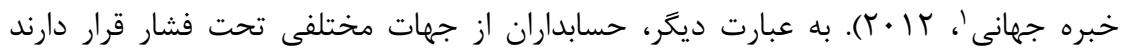

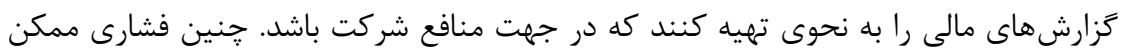
است بهواسطه عواملى مانند حفظ موقعيت شغلى، كسب پإداش و ترفيع تشديد شود (دانكن،

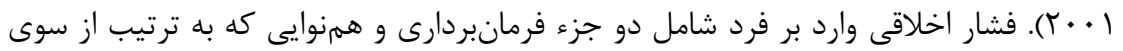

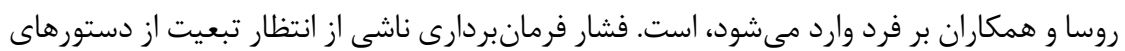

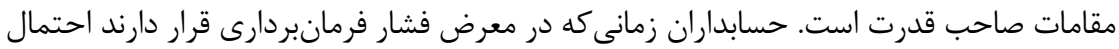

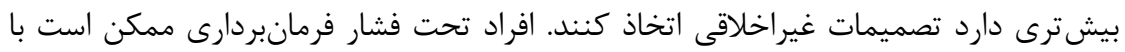

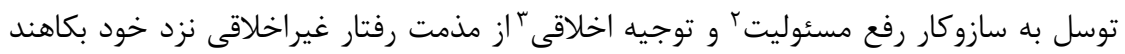

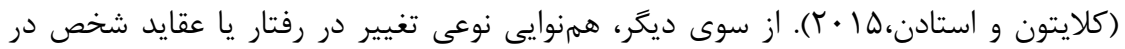

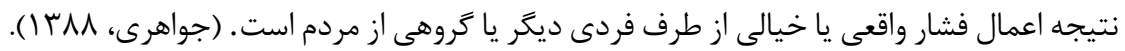

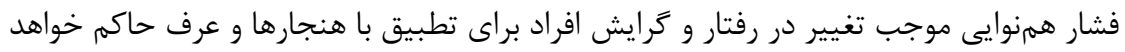
شد (دىزورت و لرد، 99 (1). جنين فشارى ناشى از ترس و و واهمه فرد از اين است كه به به عنوان

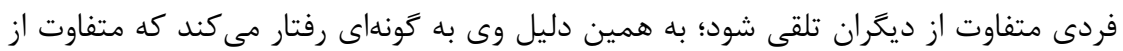
ديكران به نظر نرسد. على رغم وجود فشار براى تخطى از استانداردهاى اخلاقى، در بسيارى از موارد حسابداران از از

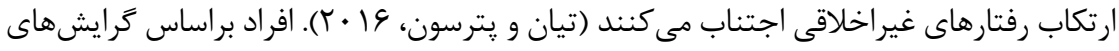

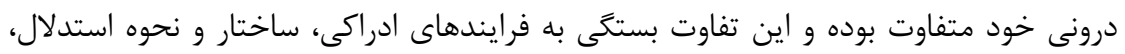

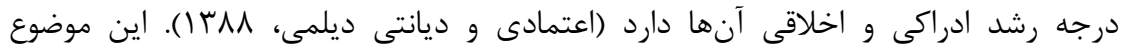

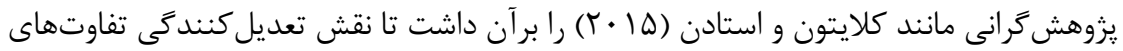

${ }^{1}$ Chartered Global Management Accountant

${ }^{2}$ Displacement of Responsibility

${ }^{3}$ Moral Justification 
فردى مانند تعهد سازمانى'، تعهد حرفهاى ' و جهت گيرى فاصله قدرت را در تمايل افراد به

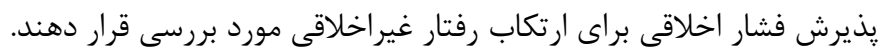

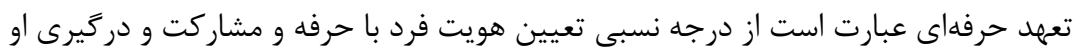

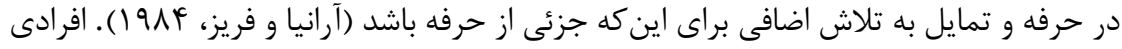

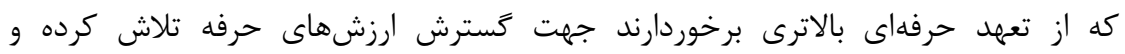

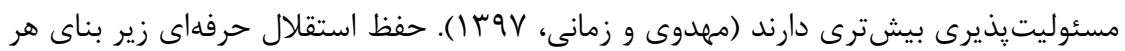

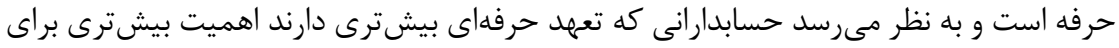

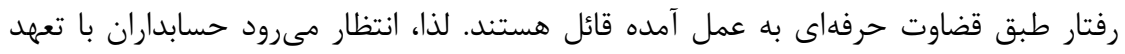

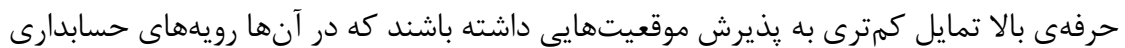

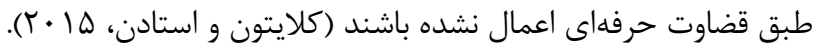

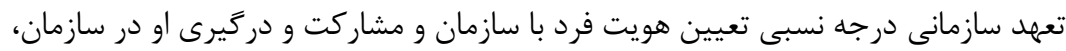

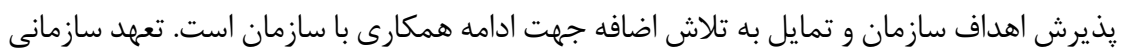

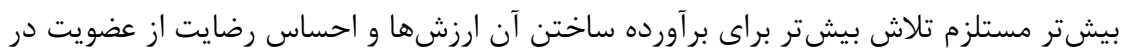

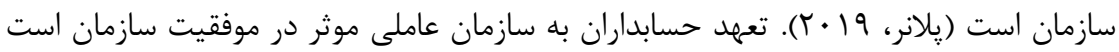

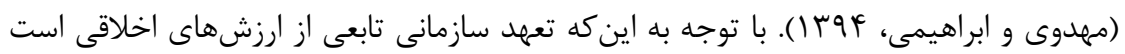

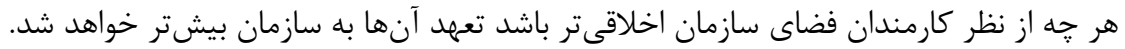

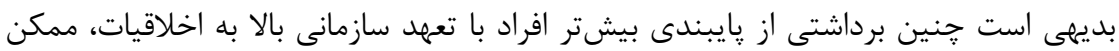

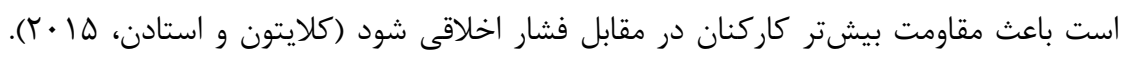

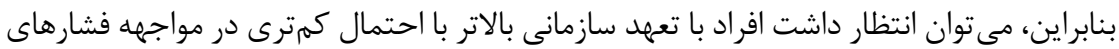
فرمانبردارى يا همنوايى مرتكب رفتارهاى غير اخلاقى شوند.

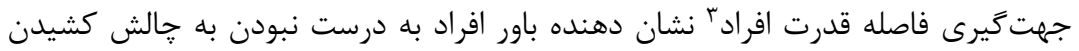

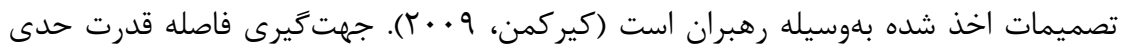

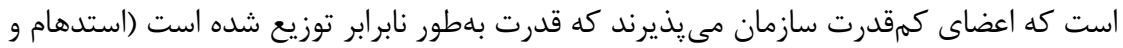

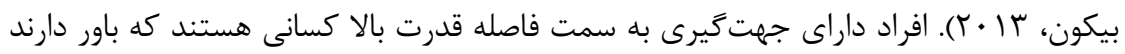

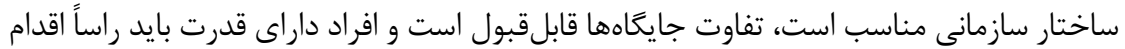

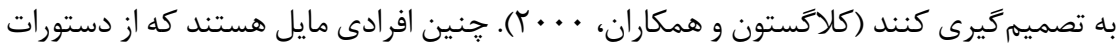

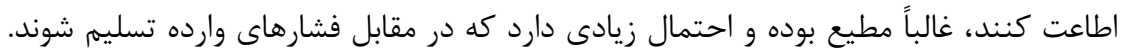

${ }^{1}$ Organizational Commitment

${ }^{2}$ Professional Commitment

${ }^{3}$ Individual Power Distance Orientation 


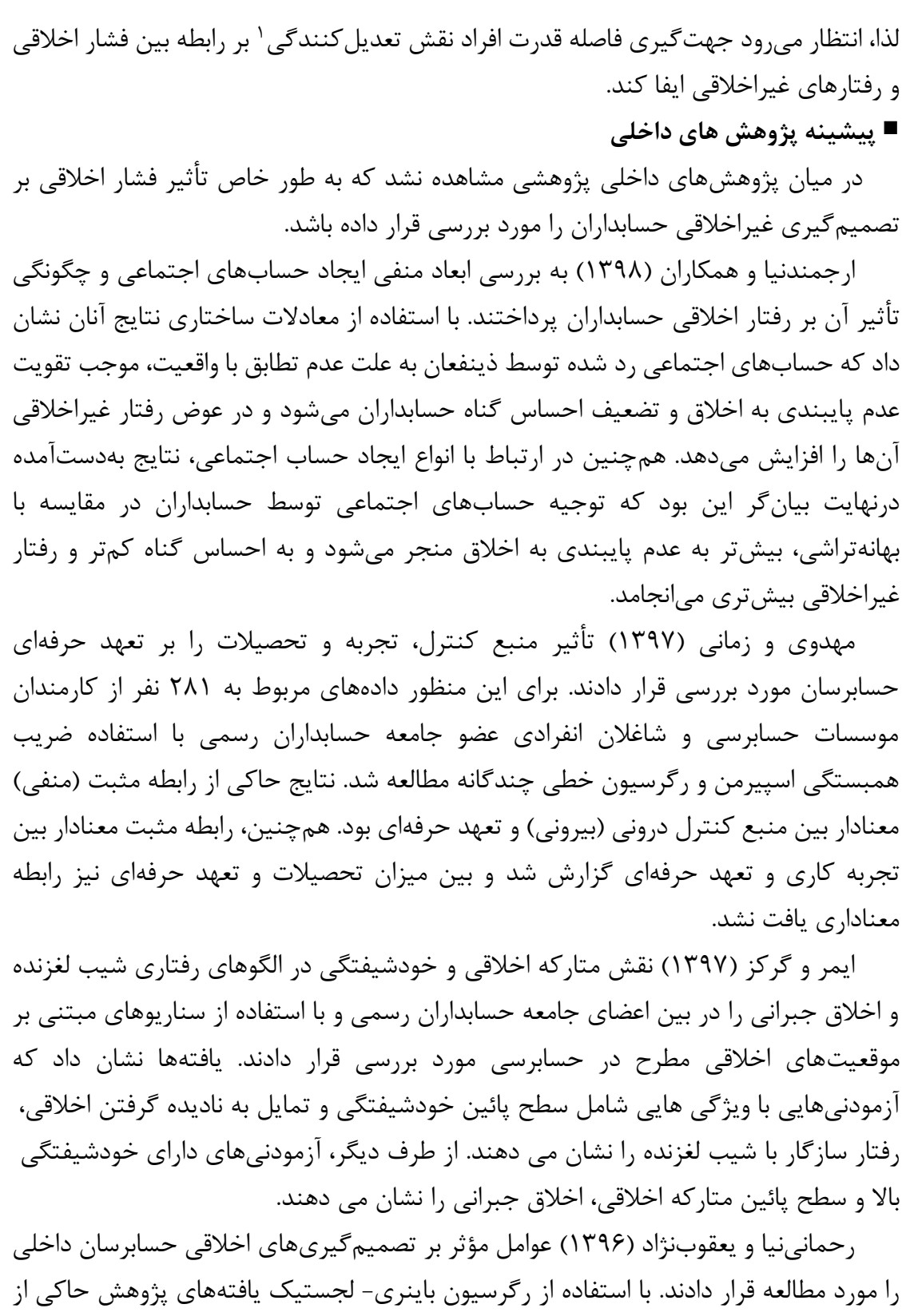

${ }^{1}$ Moderate 
دكتر مهدوى و رضالوئى، بررسى تأثير فشارهاى همنوايى و فرمانبردارى بر تصميمَيرى غيراخلاقى...

آن است كه، سن حسابرس داخلى، عضويت حسابرس داخلى در جامعلة حسابداران رسمى ايران،

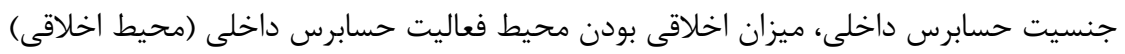

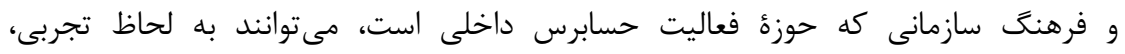

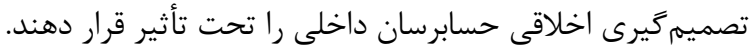

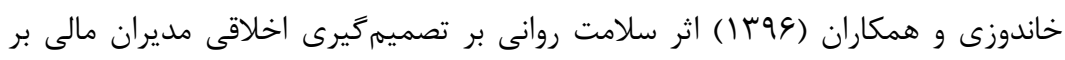

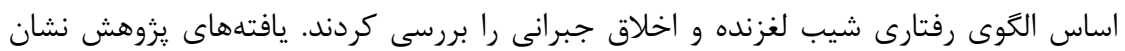

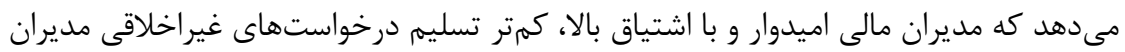

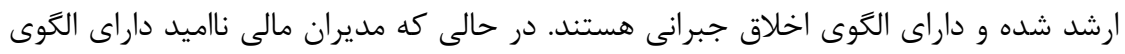

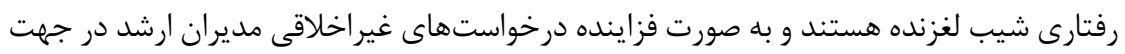

$$
\text { بهتر نشاندادن غيرواقعى عملكرد شركت را ما مى يذيرند. }
$$

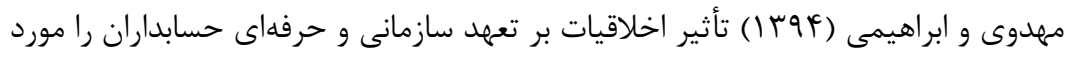

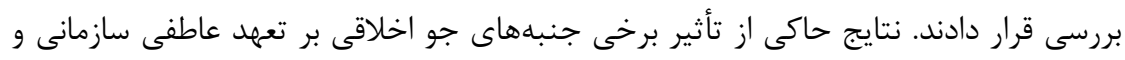

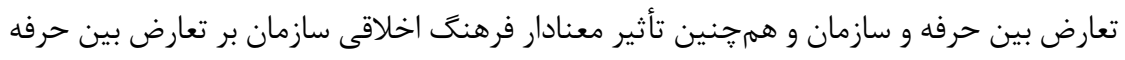

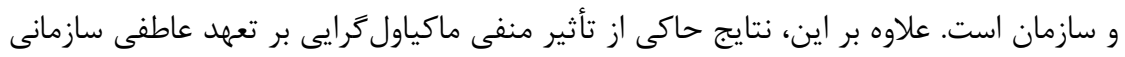

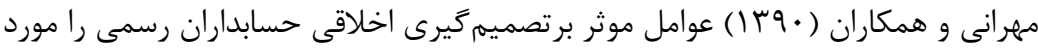

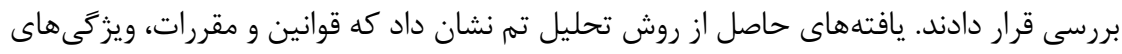

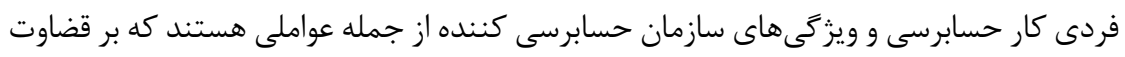
حرفهاى حسابداران رسمى اثركذار است.

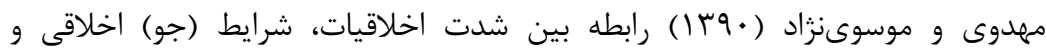

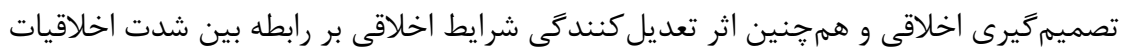

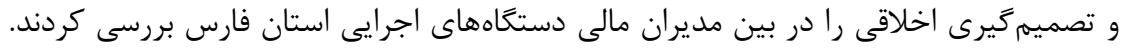

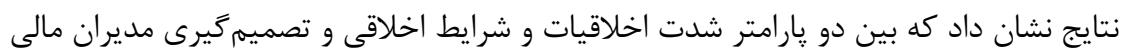

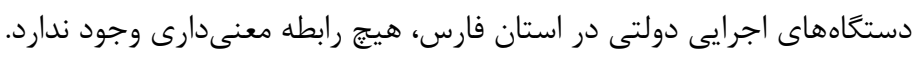

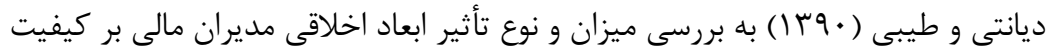

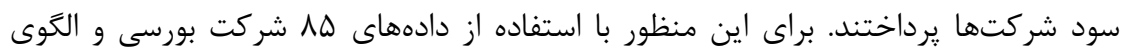

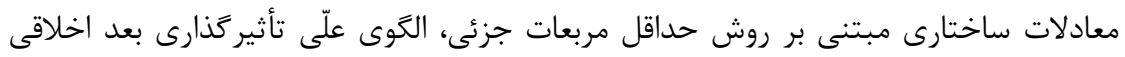

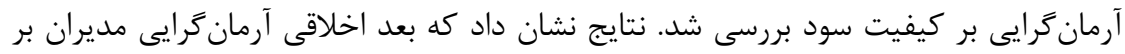

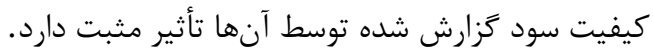




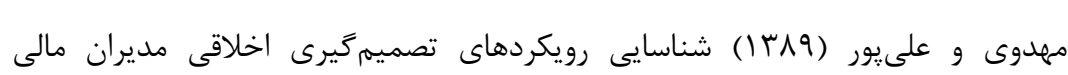

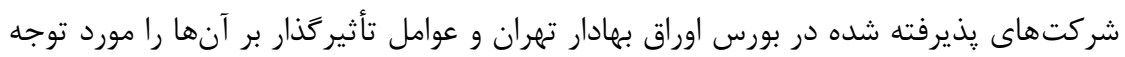

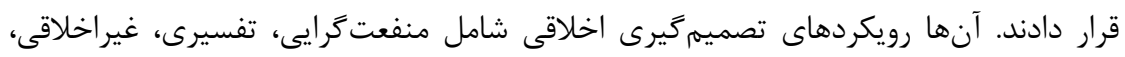

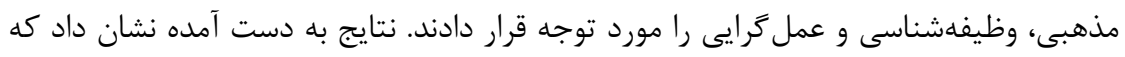

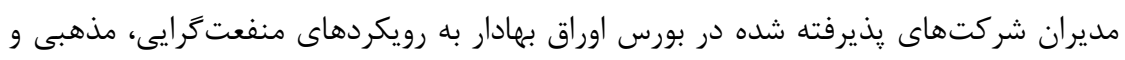
وظيفهشناسى معتقد هستند.

\section{" ييشينه يزوهش هاى خارجى}

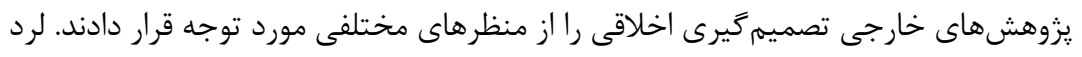

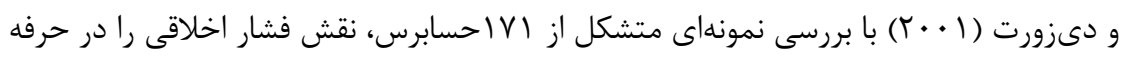

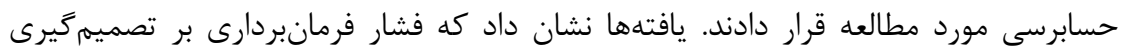

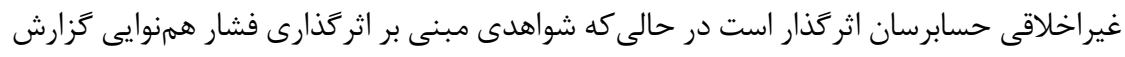
نكردند.

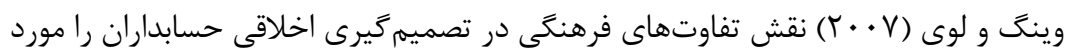

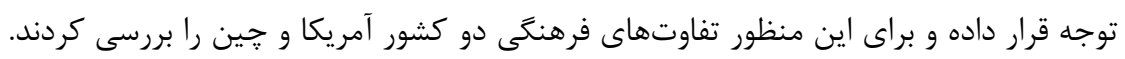

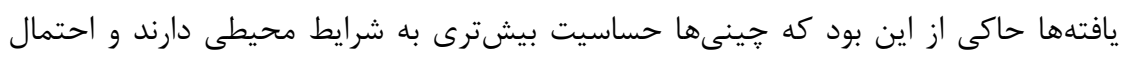

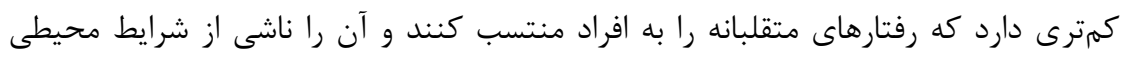

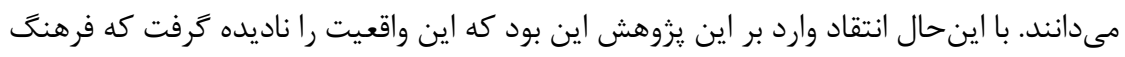
متشكل از جندين زيرمجموعه است.

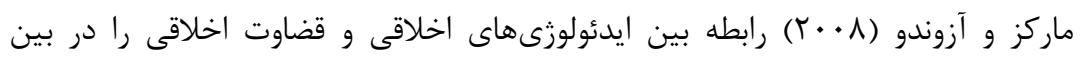

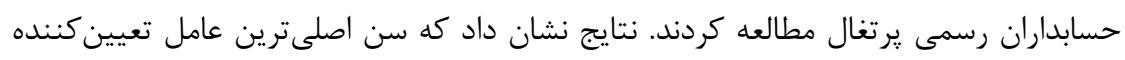
نسبى

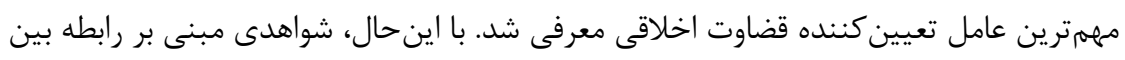

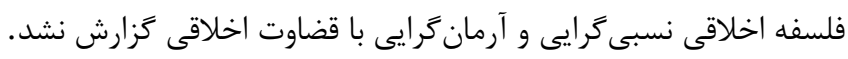

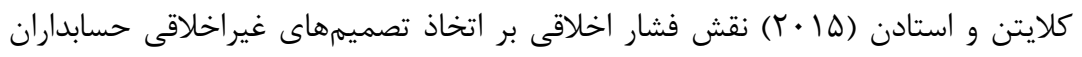

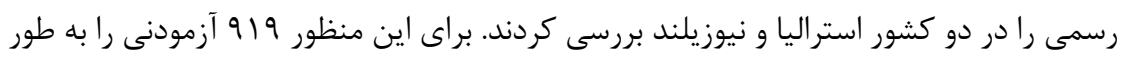

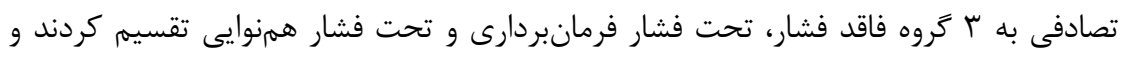

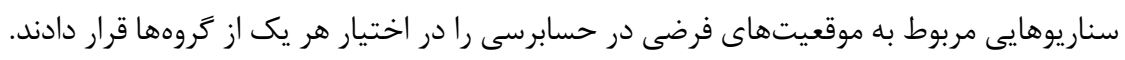

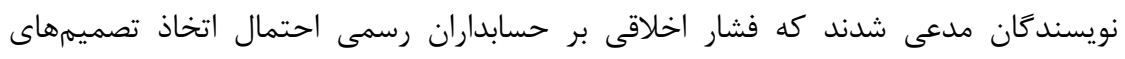

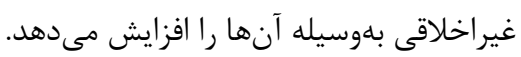




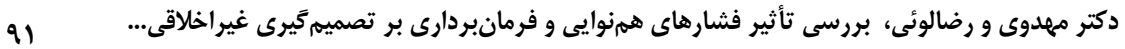

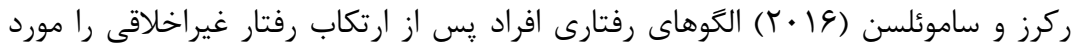

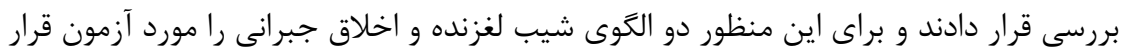

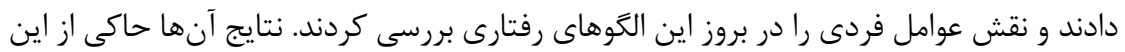

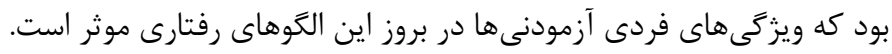

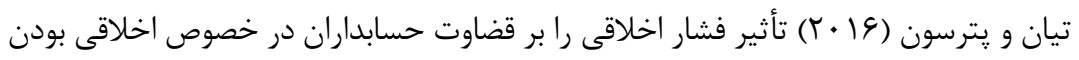

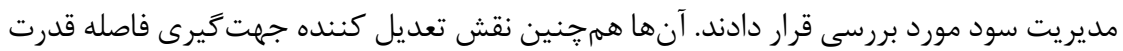

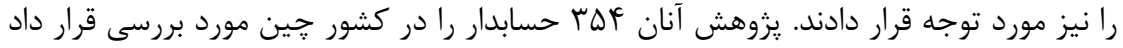

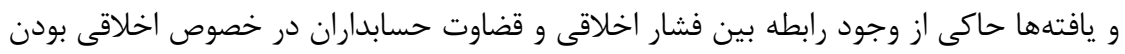

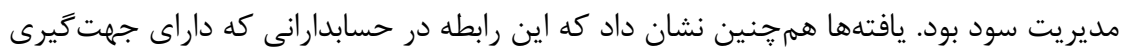
فاصله قدرت بالا هستند قوىتر است و در نتيجه نقش تعديل كنندگى جهت مورد تأييد قرار كرفت.

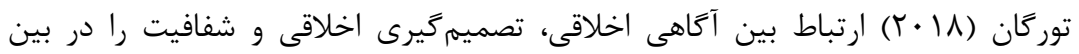

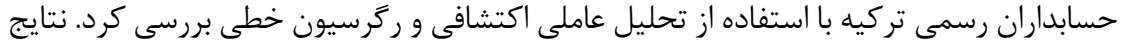

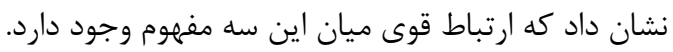

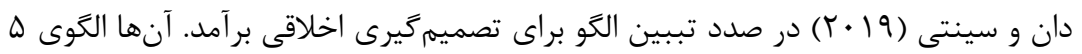

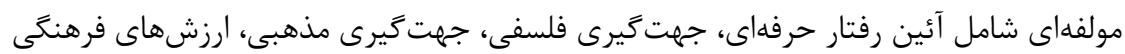
و رشد اخلاقى را براى اين منظور معرفى كردند.

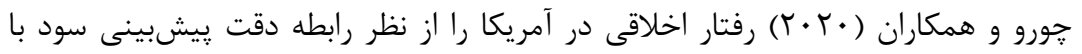

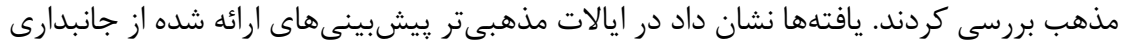

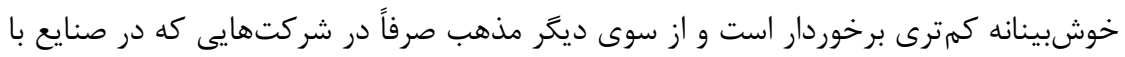

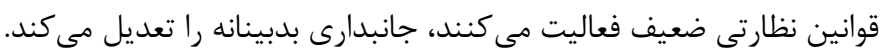

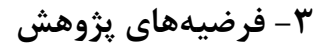

فشار اخلاقى متشكل از دو جزء فشار همنوايى و فشار فرمانبردارى است كه هر يك از آندان آنها

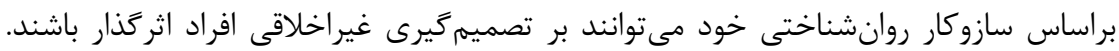

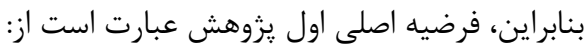

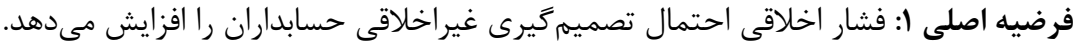

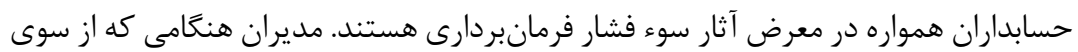

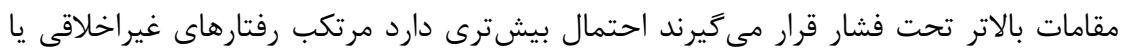


غيرقانونى شوند؛ زيرا جنين فشارى امكان منطقىسازى' رفتار غيراخلاقى را براى فرد فراهم

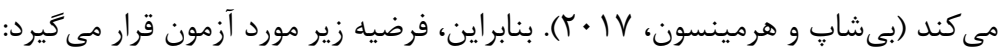

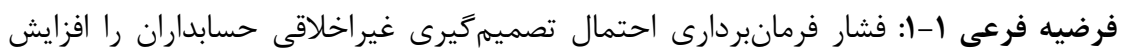

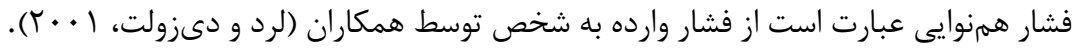

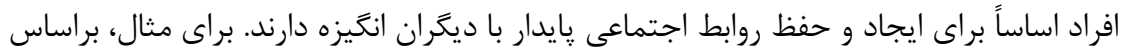

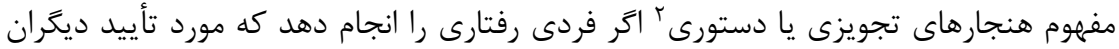

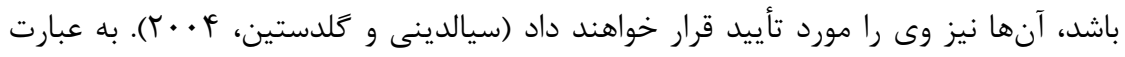

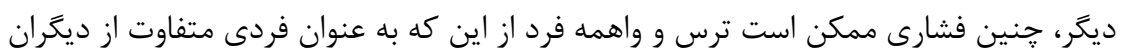

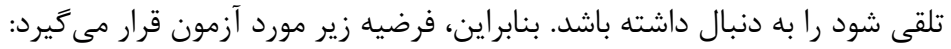

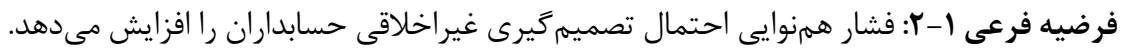

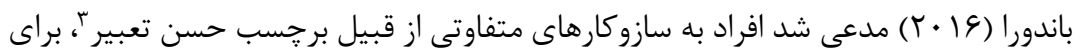

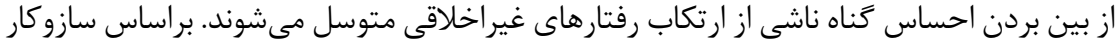

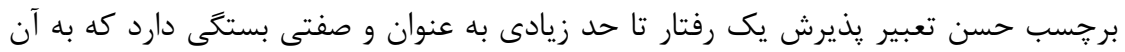

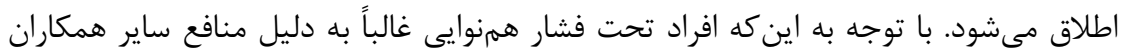
خود مرتكب رفتار غيراخلاقى مىشوند، انتظار مىرود راحتر بتوانوانداند به سازوكار مذكور برائ

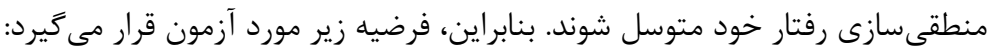

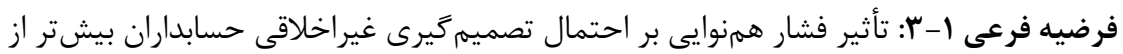
فشار فرمانبردارى است.

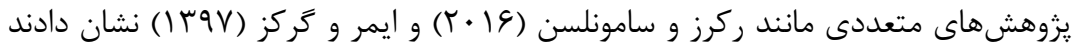
برحسب ويزگى هاى فردى و شخصيتى الكوى رفتارى و مقاومت افراد در مواجها مانه با موقعيتهاى

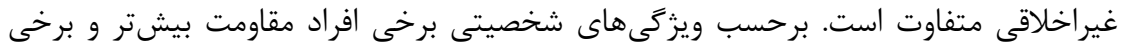

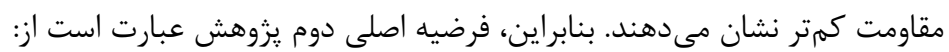

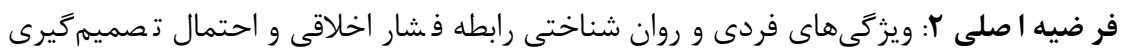
غير اخلاقى را تعديل مى كند.

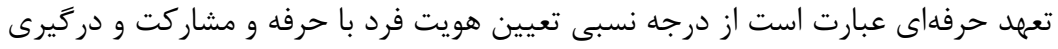

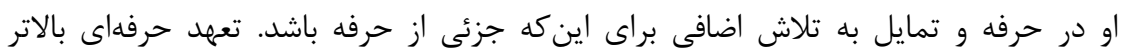

${ }^{1}$ Rationalization

${ }^{2}$ Injunctive Norms

${ }^{3}$ Euphemistic Labeling 


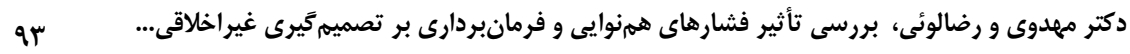

دربر گيرنده حساسيت بيشتر به اخلاق حرفهاى است (آرانيا و فريز، 91 ()). تعهد حرفهاى بالاتر افراد را به رفتار در راستاى منافع عمومى و اجتناب از رفتارهايى سوق مى دهدد كه به حرفه لطمه

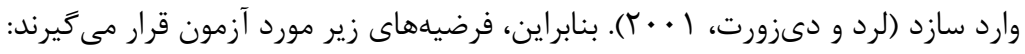
فرضيه فرعى r-ا: تعهد حرفهاى بيشتر (كمتر) احتمال تصميم گيرى غيراخلاقى حسابداران تحت فشار فرمانبردارى را كاهش (افزايش) مي دهدي. فرضيه فرعى r-r: تعهد حرفهاى بيشتر (كمتر) احتمال تصميمى تيرى غيراخلاقى حسابداران تحت فشار همنوايى را كاهش (افزايش) مى دهد. تعهد سازمانى درجه نسبى تعيين هويت فرد با سازمان و مشاركت و درگيرى او در سازمان، يذيرش اهداف سازمان و تمايل به تلاش اضافه جهت ادامه همكارى با سازمان است (يلانر،

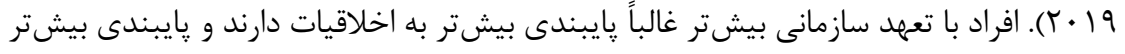

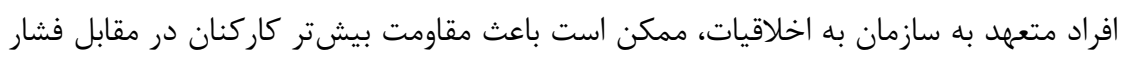

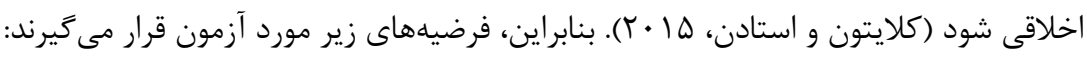
فر ضيه فرعى r-r: تعهد سازمانى بيشتر (كمتر) احتمال تصميم گيرى غيراخلاقى حسابداران تحت فشار فرمانبردارى را كاهش (افزايش) ميى دهد.

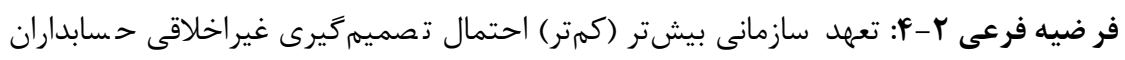
تحت فشار همنوايى را كاهش (افزايش) مى فهدئ

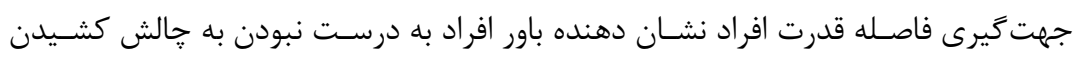

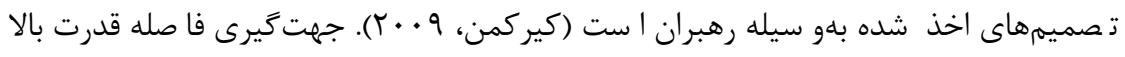

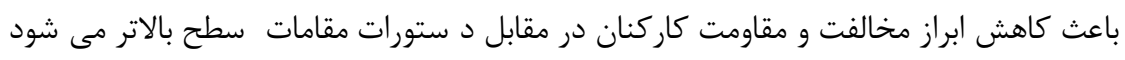

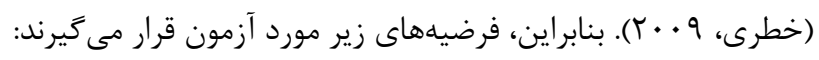

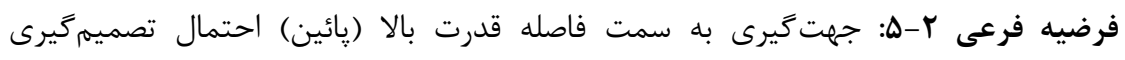
غيراخلاقى حسابداران تحت فشار فرمانبردارى را افزايش (كاهش) مي فيدهد. فرضيه فرعى r-צ: جهت گيرى به سمت فاصله قدرت بالا (يائين) احتمال تصميمى فيرى

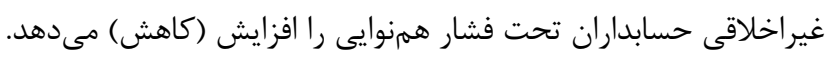

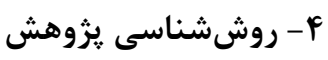

يزوهش حاضر براساس هدف از نوع كاربردى، از نظر زمان از نوع مقطعى، از نظر جمعآورى دادهها از نوع توصيفى و شبهتجربى و از نوع يروهشهاى ييمايشى است. جامعه آمارى يروهش

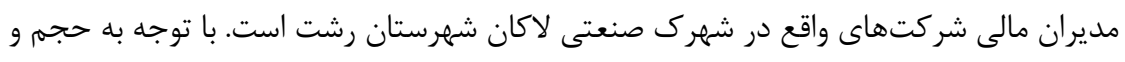

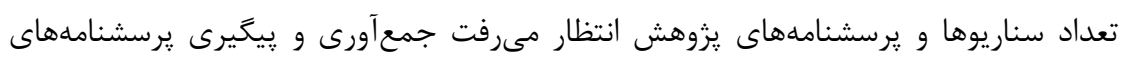




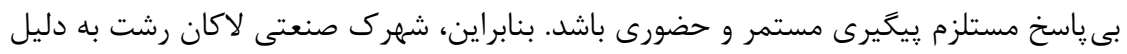

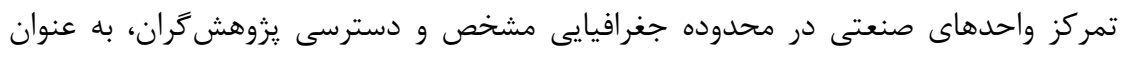

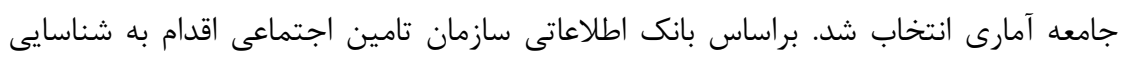

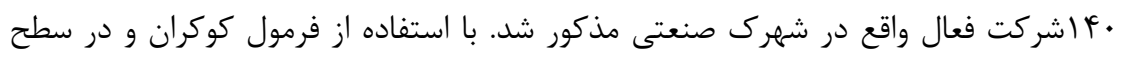

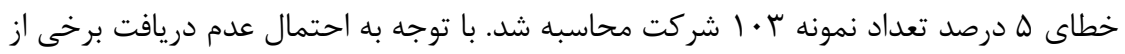

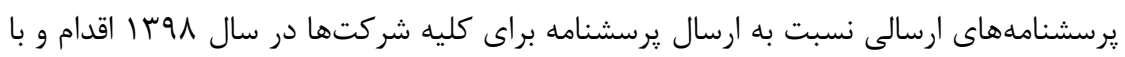

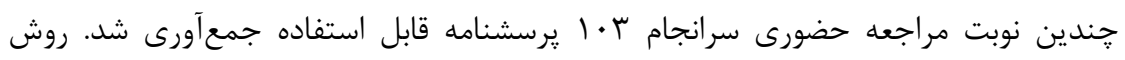

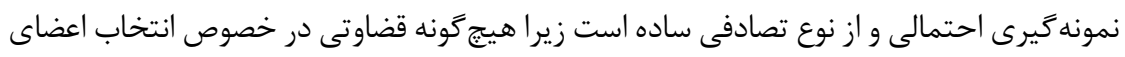

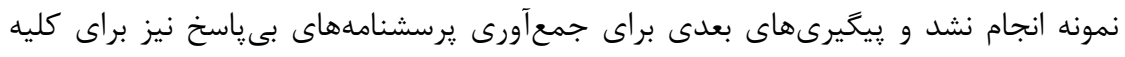

$$
\mathrm{N}=\frac{\frac{z^{2} p q}{d^{2}}}{1+\frac{1}{N}\left(\frac{z^{2} p q}{d^{2}}-1\right)}=102.5 \quad \mathrm{z}=1 / 94 \quad \mathrm{p}=\mathrm{q}=/ \mathrm{Q}
$$

$$
\mathrm{N}=\mid \boldsymbol{r} \text {. }
$$

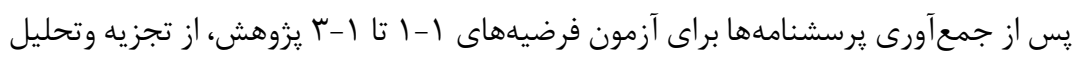

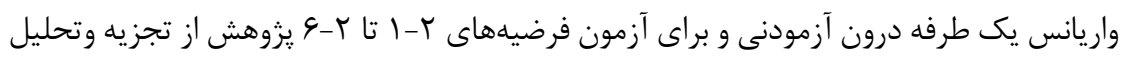

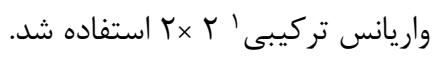

\section{متغير هاى مستقل}

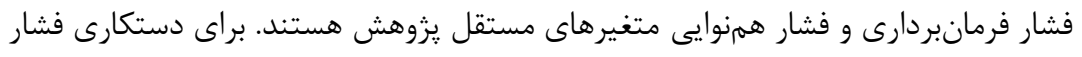

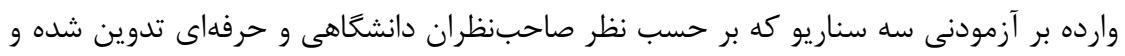

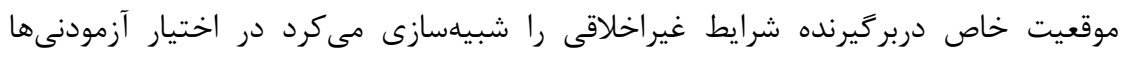

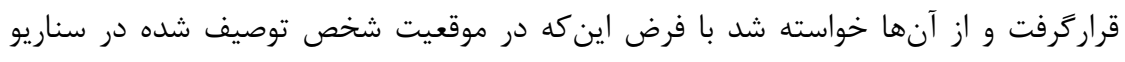

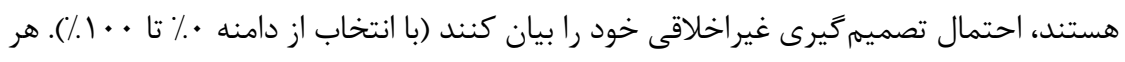

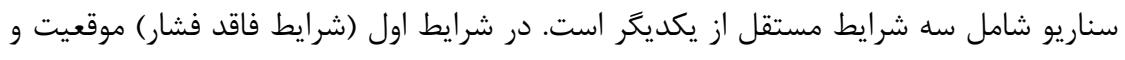

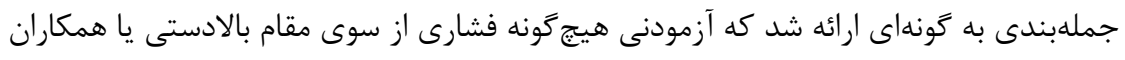

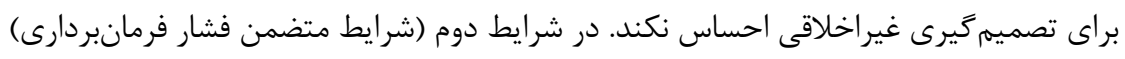

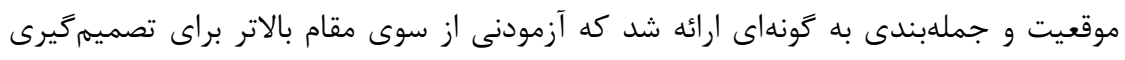

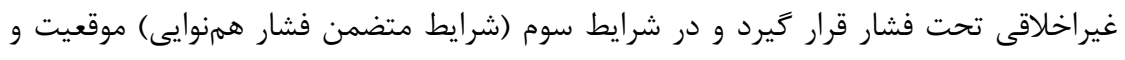

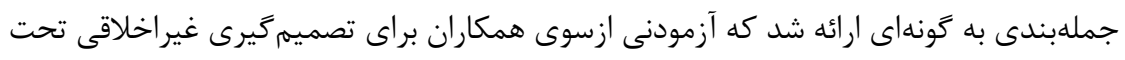

${ }^{1}$ Mixed ANOVA 
فشار قرار گيرد. به عبارت ديغر، هر آزمودنى در هر سناريو در معرض ب موقعيت فاقد فشار،

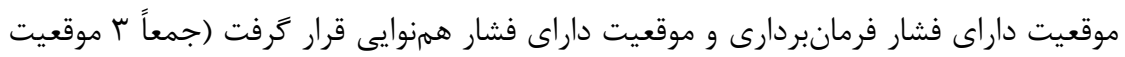

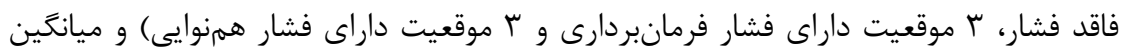
احتمال موافقت وى با درخواست غيراخلاقى در هر موقعيت غير اخلاقى محاسبه شد. دليل استفاده

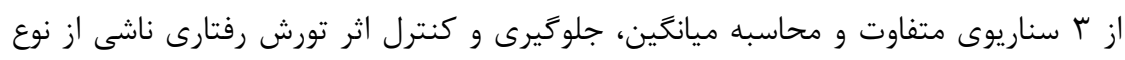

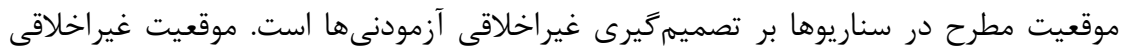

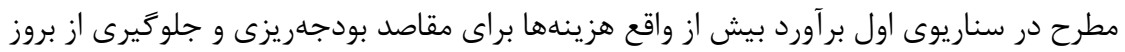

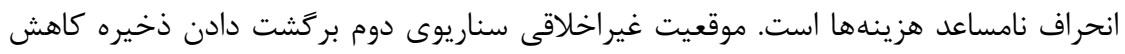

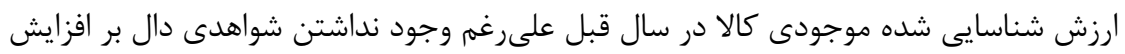

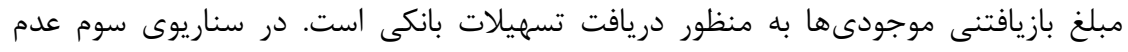

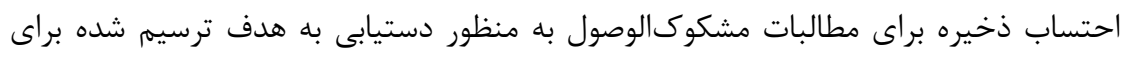
دايره وصول مطالبات مطرح شد. متغير وابسته

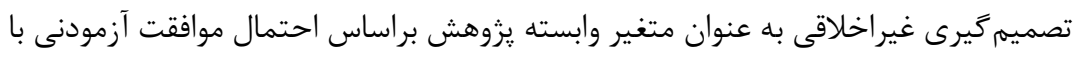

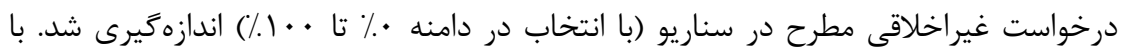

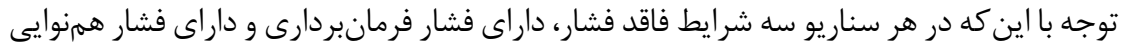

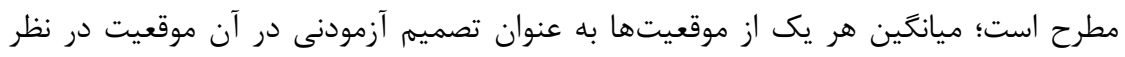
كرفته شد.

\section{متغيرهاى تعديلكر}

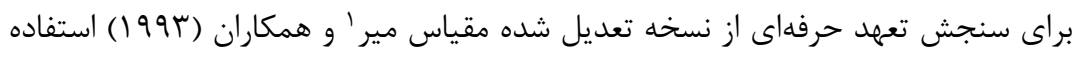

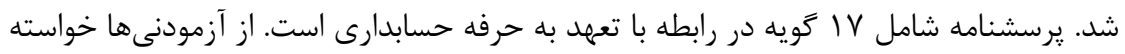

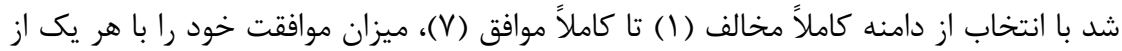

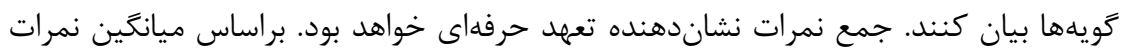

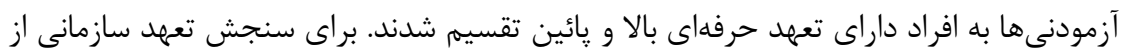

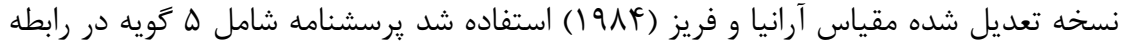

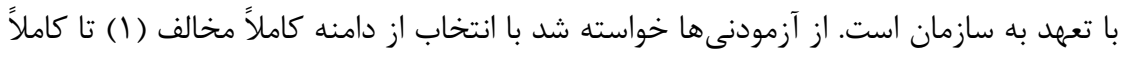

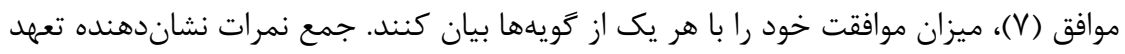

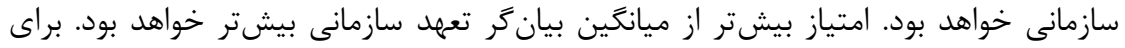

\footnotetext{
${ }^{1}$ Meyer
} 


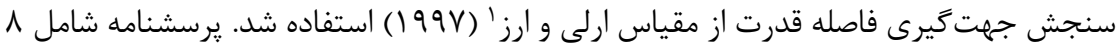

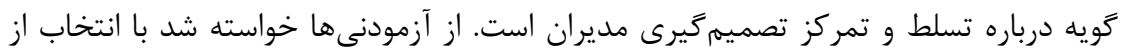

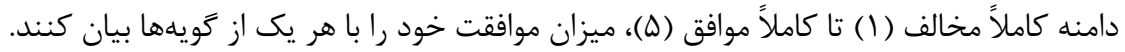
جمع نمرات نشاندهنده جهت گيرى فاصله قدرت خواهد بود. امتياز بيشتر از ميانكين بيانكر مانر جهت گيرى فاصله قدرت بيشتر خواهد بود ندان

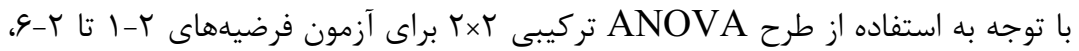

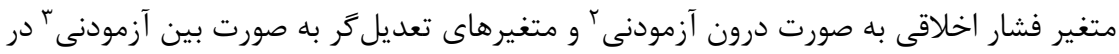

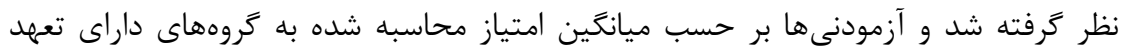

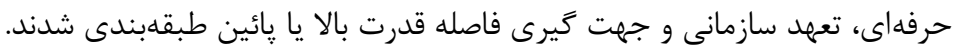

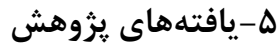

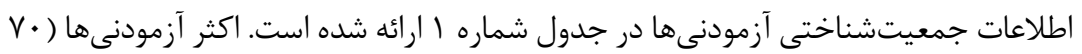

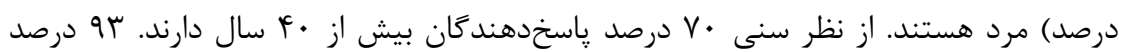
ياسخدهند

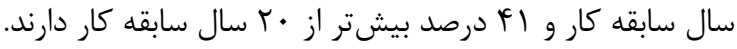
جدول ا. اطلاعات جمعيتشناختى آزمونىها لارنها

\begin{tabular}{|c|c|c|c|c|c|}
\hline درصد & تعداد & |متغير & درصد & نعداد & متغير \\
\hline & & تحصيلات & & & |جنسيت \\
\hline.$/ \cdot r$ & r & |دييلم & $\cdot / \mu$ & r & |زن \\
\hline$\cdot 1 \cdot \Delta$ & $\Delta$ & كارداني & $\cdot / V$ & VT & رد \\
\hline$\cdot / \Delta F$ & $\Delta \varphi$ & كا,شناس & & & \\
\hline 莎 & זr & كارشناسى ارشد & & & \\
\hline$\cdot / \cdot V$ & v & دكترى & & & \\
\hline & & سابقه كار & & & \\
\hline 1 & 1 & كمتر از ه سال & $\cdot / \mu$ & r & 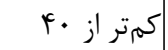 \\
\hline$\cdot / r \Delta$ & rq & هـ تا 9 سال & 落 & $r v$ & بين ·F تا ما \\
\hline r & rF & •ا تا • r سال & $\cdot / \mu F$ & ro & بيشتر از • ه \\
\hline il & Ft & بيش از • r سال & & & \\
\hline
\end{tabular}

${ }^{1}$ Earley and Erez

${ }^{2}$ With In Subject

${ }^{3}$ Between Subject 


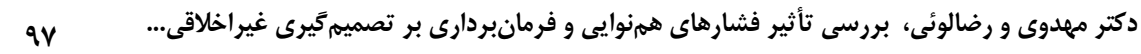

\begin{tabular}{|c|c|c|c|c|c|c|c|}
\hline جولَّى & كشيدگى & كمينه & بيشينه & انحراف & ميانگين & \multicolumn{2}{|l|}{ شرح } \\
\hline .199 & -.190 & r. & VT & $11 / r \Delta$ & Fै/9V & & سن \\
\hline$\cdot 19$ & $-\cdot 19$ & f & FV & it & $r 1 / \cdot 1$ & & سابقه كار \\
\hline$\cdot|\Delta|$ & $-\cdot 10$ & $\cdot$ & 1 & $\cdot|r|$ & $\cdot 1 / 4$ & بدون فشار & احتمال \\
\hline$-\cdot \cdot \cdot f$ & $-\cdot 1 \wedge \Delta$ & • & 1 & $\cdot / T \Delta$ & $\cdot / r \Lambda$ & فشار فرمانبردارى & تصميم گيرى \\
\hline 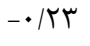 &.$- \cdot 199$ & • & 1 & $\cdot 1 / 99$ & $\cdot 10 \cdot$ & فشار همنوايى & غير اخلاقى \\
\hline.$/ 14$ &.$- / 1 T$ & $r$. & 119 & IV/TR & $V \wedge / Y I$ & & تعهد حرفهاى \\
\hline.$- / 19$ & -.1 .9 & $\Lambda$ & ra & $\Delta / V T$ & $r \mu / Q F$ & & تعهد سازمانى \\
\hline$\cdot 1 \cdot V$ & $1 / 90$ & 11 & r. & F/V & $r d / r r$ & اصله قدرت & جهت گيرى فا. \\
\hline
\end{tabular}

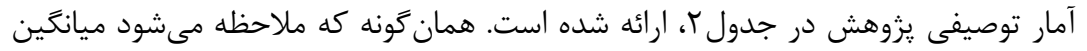

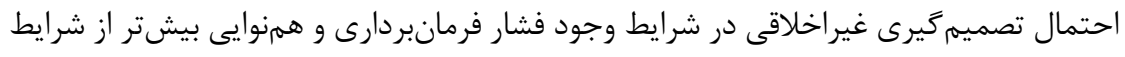

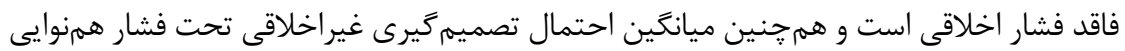

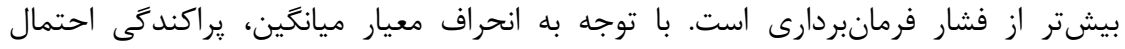

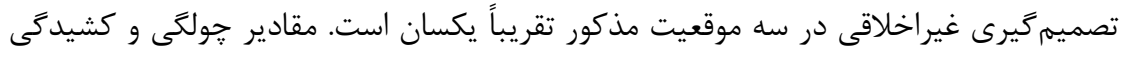

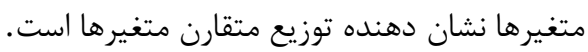

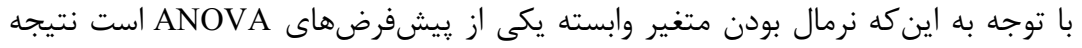

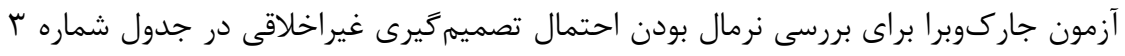

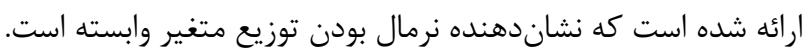

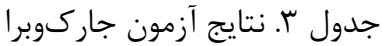

\begin{tabular}{|c|c|c|c|}
\hline تفسير & احتمال & آماره جاركوبرا & احتمال تصميمكيرى غيراخلاقى \\
\hline نرمال & .1 .94 & $\Delta / \Delta V$ & شرايط فاقد فشار اخلاقى \\
\hline 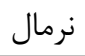 &.$/ 19 V$ & $r / T \Delta$ & شرايط فشار فرمانبردارى \\
\hline 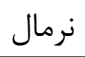 & $\cdot / \cdot V F$ & $\Delta / Y)$ & شرايط فشار همنوايى \\
\hline
\end{tabular}

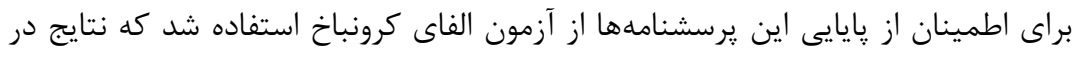

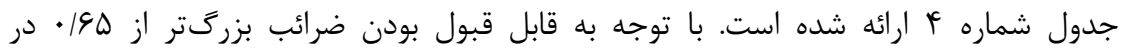

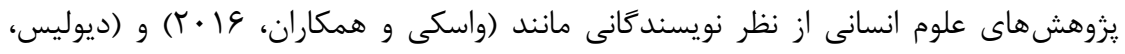

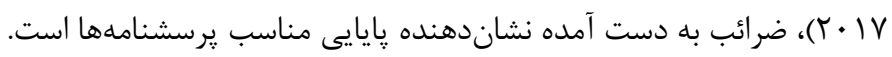




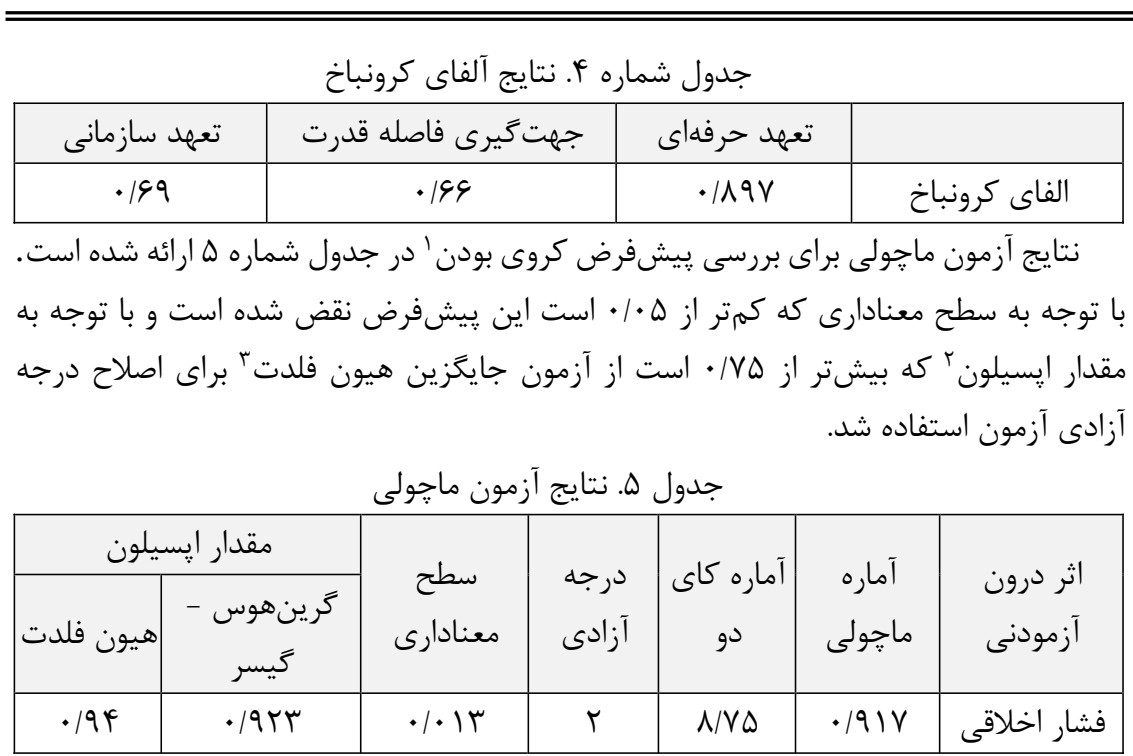

نتايج تجزيه و تحليل واريانس يك طرفه و مقايسه دو به دوى ميانگينها براى آزمون

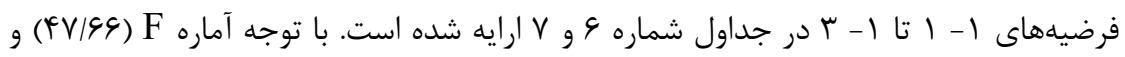
سطح معنادارى ( · · • • ) ارائه شده در جدول شماره و مىتوان نتيجه گيرى كرد كه تفاوت معنادار در ميانگينها وجود دارد و به بيان ديخر وجود فشار اخلاقى بر تصميمثيرى غيراخلاقى موثر

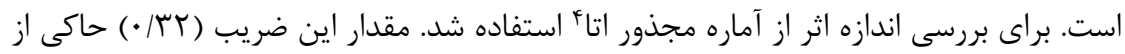

$$
\text { اثر بزرگ ه فشار اخلاقى بر تصميم گيرى غيراخلاقى است. }
$$

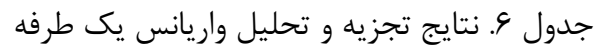

\begin{tabular}{|c|c|c|c|c|c|}
\hline ETA & سطح معنادارى & F آماره F & درجه آزادى & آماره & عامل \\
\hline$\cdot / M Y$ & $.1 \cdot$ & FV/G9 & $1 / 1 \vee q$ & هيون فلدت & فشار اخلاقى \\
\hline
\end{tabular}

براى تفسير دقيقتر تفاوت ميانكينها، نتايج آزمون تعقيبى بونفرونى \براى مقايسه دو به

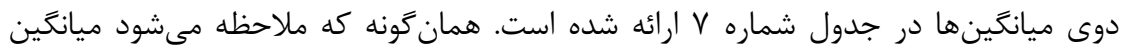

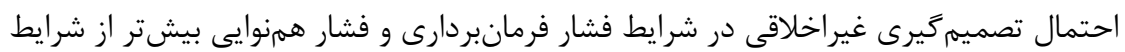

${ }^{1}$ Sphericity

${ }^{2}$ Epsilon

${ }^{3}$ Huynh-Feldt

${ }^{4}$ Partial Eta Squared

${ }^{5}$ Large Effects

${ }^{6}$ Bonferroni Post Hoc Test 

دكتر مهدوى و رضالوئى، بررسى تأثير فشارهاى همنوايى و فرمانبردارى بر تصميمتيرى غيراخلاقى...

فاقد فشار است و همهنين ميانگين احتمال تصميمَيرى غيراخلاقى در شرايط فشار همنوايى

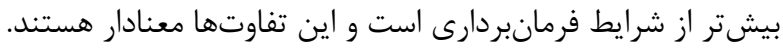

جدول V. نتايج آزمون بونفرونى براى مقايسه دو به دوى ميانخينها

\begin{tabular}{|c|c|c|c|c|c|}
\hline تقسير & فرضيه & معنادارى سطح & ميانگَنلاف & \multicolumn{2}{|c|}{ عامل } \\
\hline عدم رد فرضيد & فرضيه |-1 & $\cdot 1 \cdot \cdot r$ &.$/ 1 Y$ & فشار فرمانبردارى & فاقد فشار اخلاقى \\
\hline عدم رد فرضيه & فرضيه |- & $\cdot 1 \cdot \cdots$ & $\cdot / T F$ & فشار همنوايى & فاقد فشار اخلاقى \\
\hline عدم رد فرضيه & |فرضيه 1-r & $\cdot 1 \cdot \cdots$ & $\cdot / 1 Y$ & |فشار همنوايى & فشار فرمانبردارى \\
\hline
\end{tabular}

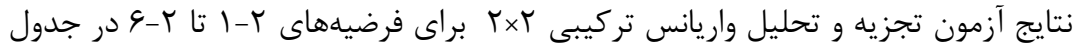

شماره 1 ارائه شده است.

\begin{tabular}{|c|c|c|c|c|c|c|c|c|c|}
\hline \multirow{2}{*}{ رد رد رضيد } & \multirow[b]{2}{*}{ فرضيه } & \multicolumn{3}{|c|}{ 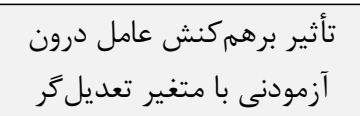 } & \multicolumn{2}{|c|}{ تأثير عامل فشار } & \multirow{2}{*}{$\begin{array}{l}: 3 \\
3 \\
3 \\
3 \\
3 \\
3\end{array}$} & \multirow{2}{*}{\multicolumn{2}{|c|}{ نوع فشار اخلاقى }} \\
\hline & & ضريب اتا & معنادارى & آماره F & معنادارى & F آماره F & & & \\
\hline عدم رد & $1-r$ & $\cdot 1 \cdot 1$ & $\cdot 1 \cdot$ & $9 / 11$ & $\cdot 1 \cdot$ & $T F / V$ & 3 & فرمانبردارى & $\frac{9}{39}$ \\
\hline رد & $r-r$ &.$/ \cdot r$ & $\cdot 110$ & $r / \cdot \Delta$ & $.1 \cdots$ & $V T / I I$ & $\frac{.2}{y}$ & همنوايى & 3 \\
\hline رد & $r-r$ & $\cdot / \cdot v$ & • & - /VA & $.1 \ldots$ & $r \varepsilon / q$. & $\begin{array}{l}: 3 \\
3\end{array}$ & فرمانبر دارى & :9, \\
\hline رo & $r-r$ &.$/ \cdot r$ & س & אז/. &.$/ \ldots$ & $V E / T$. & $\ddot{s}$ & همنوايى & 3 \\
\hline عدم رد & $\Delta-r$ & .1 .9 &.$/ .14$ & $G / F \Delta$ & $\cdot 1 \cdot$ & $T V / G Y$ & $\frac{9}{3}$ & فرمانبردارى & :98 \\
\hline رد & G-r & $\cdot 1 \cdot r$ & $\cdot 1 \cdot 1$ & $r / \cdot V$ & $.1 \cdots$ & $V \varepsilon / \cdot F^{c}$ & ? & همنوايى & 3 \\
\hline
\end{tabular}

همانطور كه در ستون مربوط تأثير عامل درون آزمودنى ملاحظه مىشود با توجه به سطح

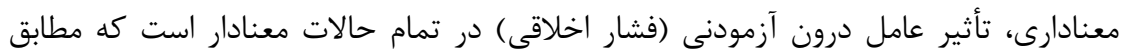

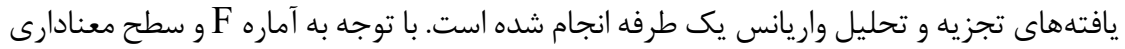

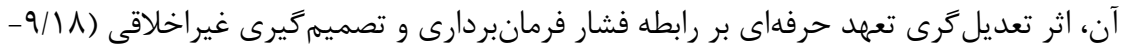

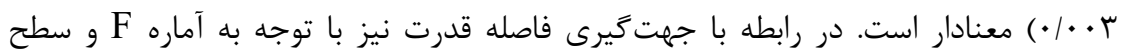




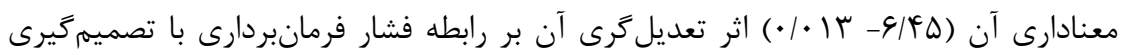

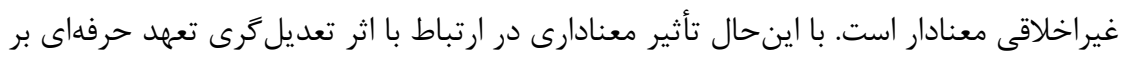
رابطه فشار همنوايى و تصميمَيرى غيراخلاقى، اثر تعديل

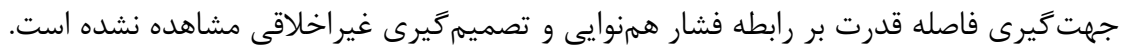

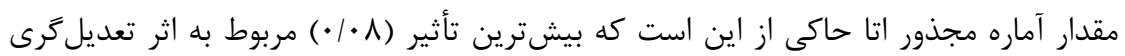

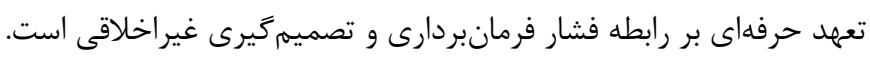

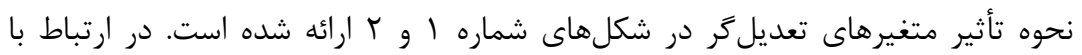

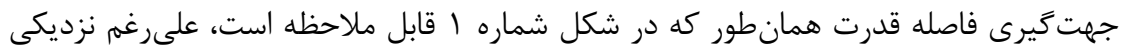

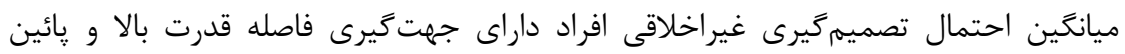

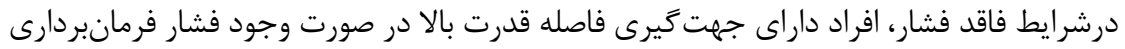

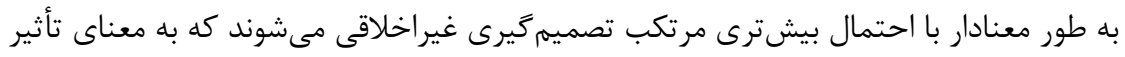
تعديل

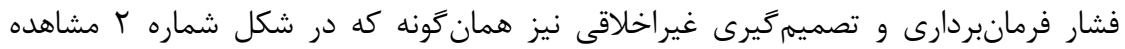

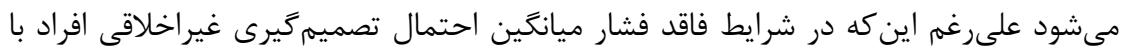

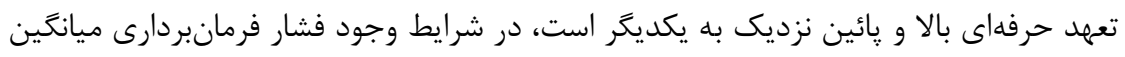

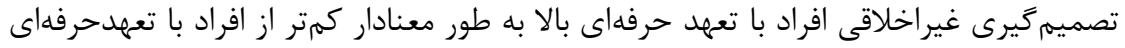

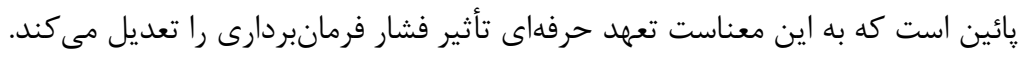

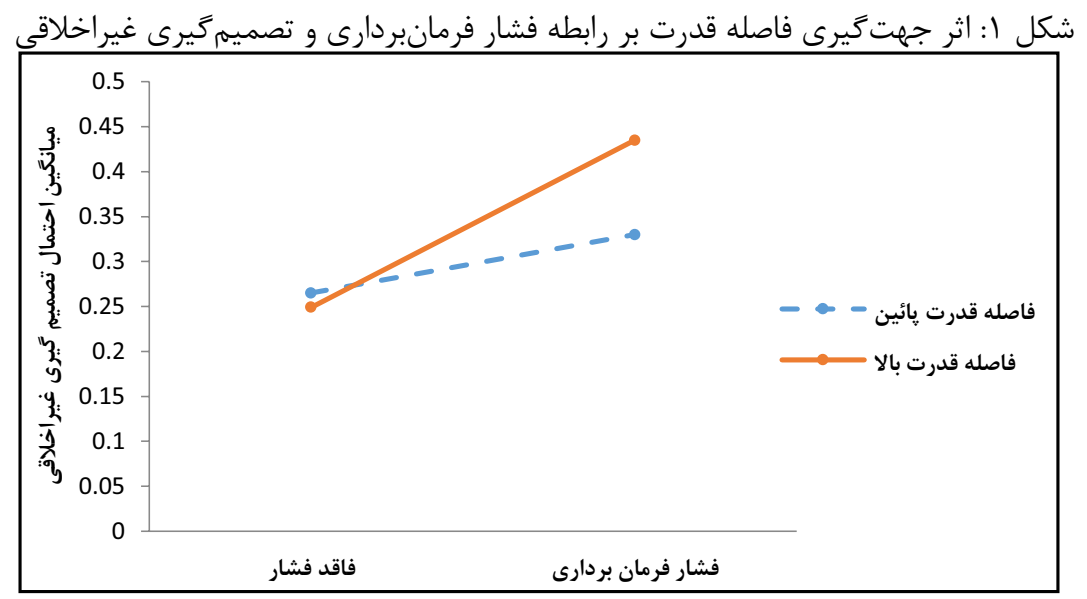


دكتر مهدوى و رضالوئى، بررسى تأثير فشارهاى همنوايى و فرمانبردارى بر تصميمَيرى غيراخلاقى... 1.

شكل r: اثر تعهد حرفهاى بر رابطه فشار فرمانبردارى و تصميمَيرى غيراخلاقى

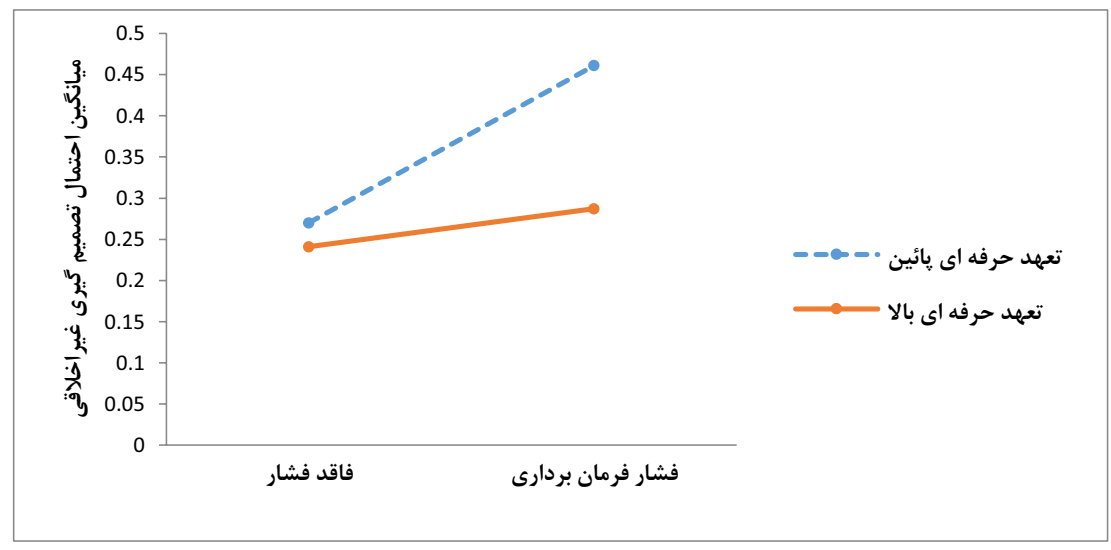

4- ونتيجه كيرى و بحث

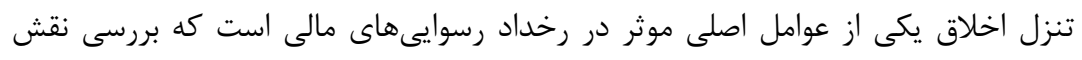

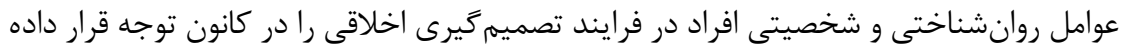

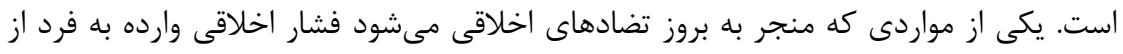

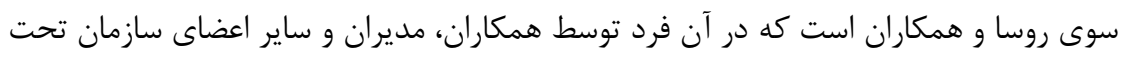

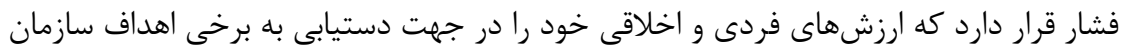

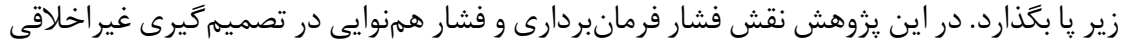

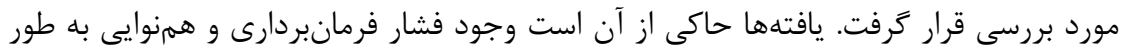

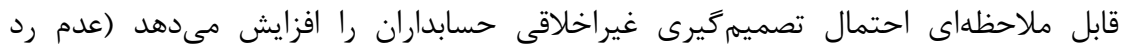

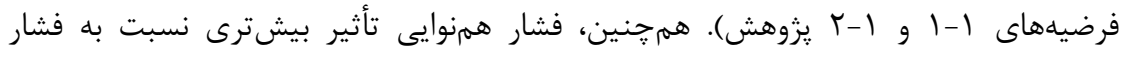

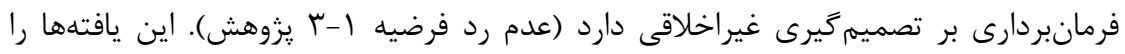

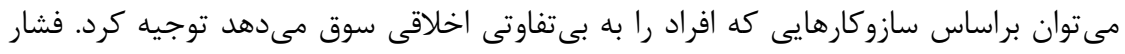

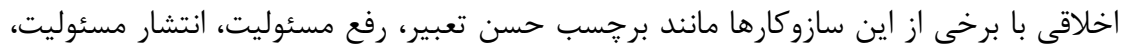

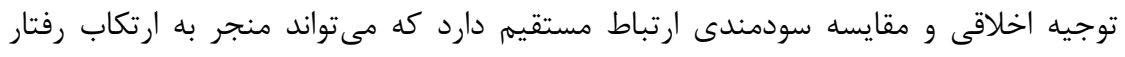

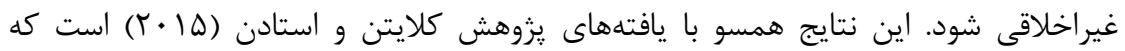

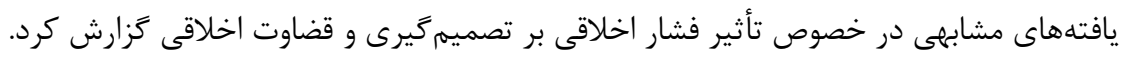

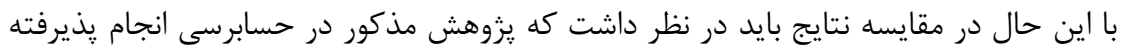

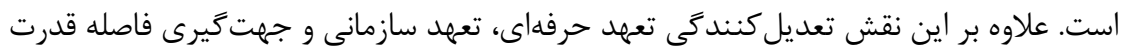


بر رابطه فشار فرمانبردارى و فشار همنوايى و تصميمَيرى غيراخلاقى نيز مورد بررسى قرار

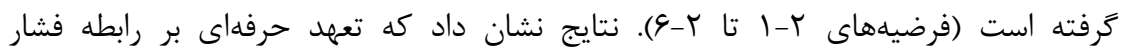

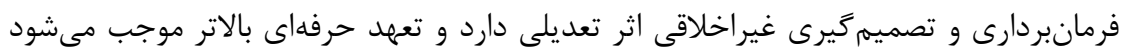

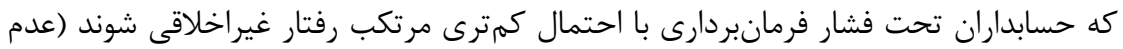

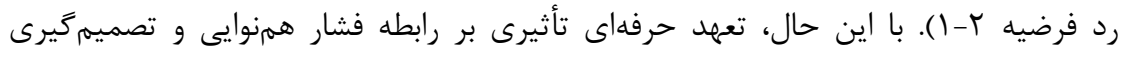

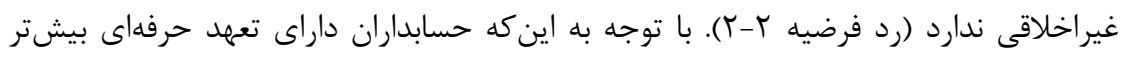

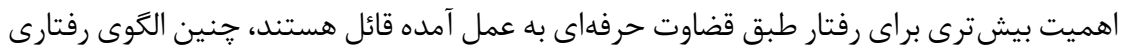

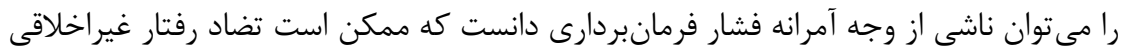

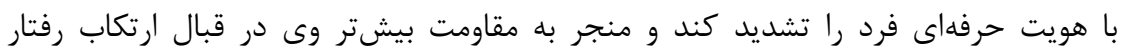
غيراخلاقى شود. در ارتباط با جهت گيرى فاصله قدرت نيز نتايج حاكى از اثر تعديلى جهت

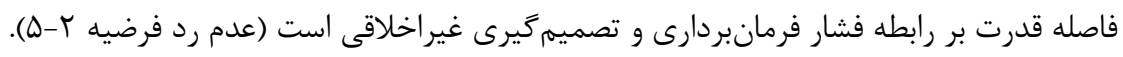

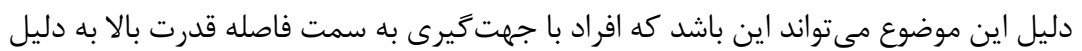

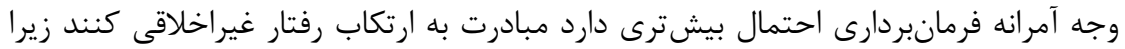

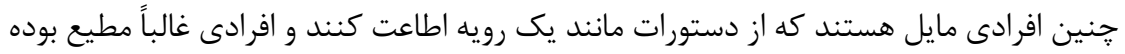

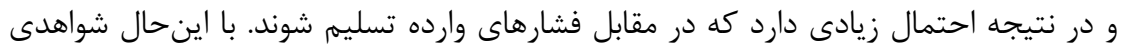

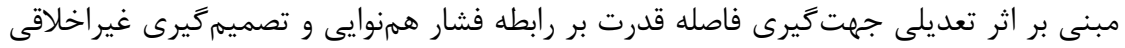

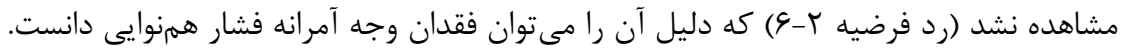

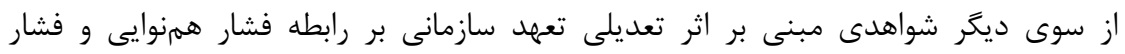

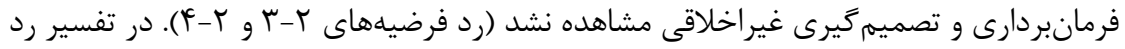

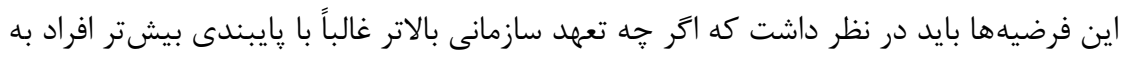

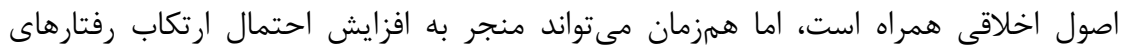

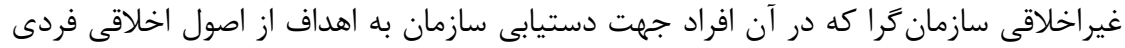

$$
\text { خود عبور مى كنند، شود. }
$$
از محدوديتهاى يزوهش حاضر استفاده از سناريوهاى مبتنى برموقعيتهاى فرود فرضى است.

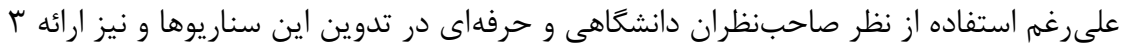

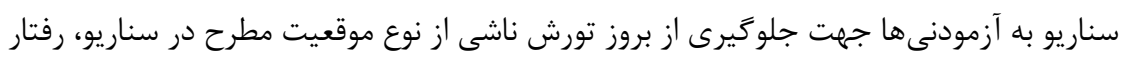

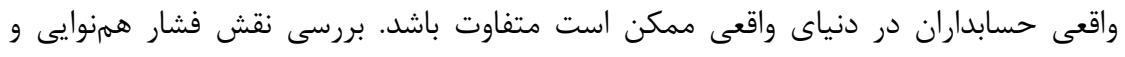

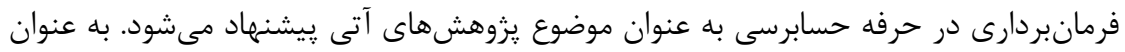

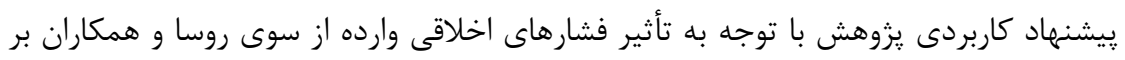

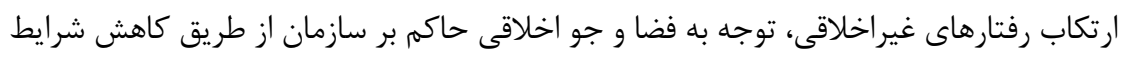




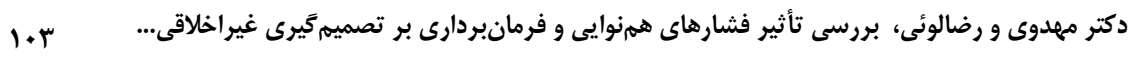

موجد فشارهاى اخلاقى بر حسابداران مورد تأكيد قرار مى گيرد. همرجنين با توجه به افزايش

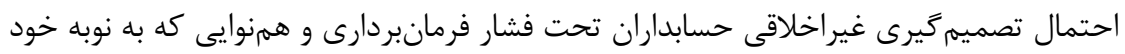
كاهش كيفيت كزارش

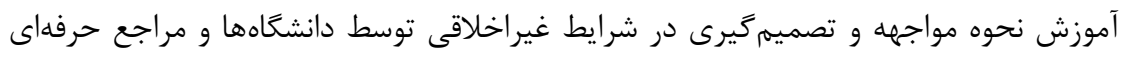

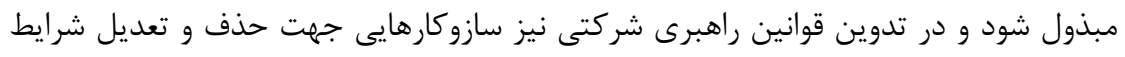

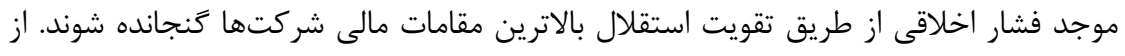

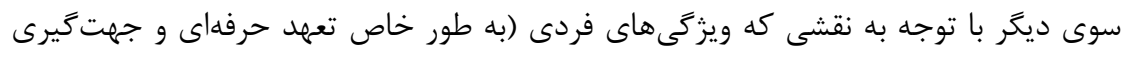

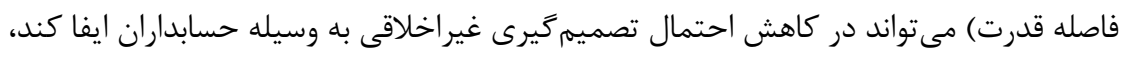

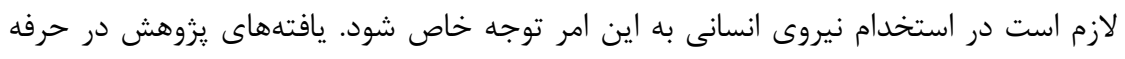

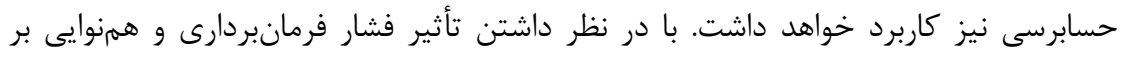

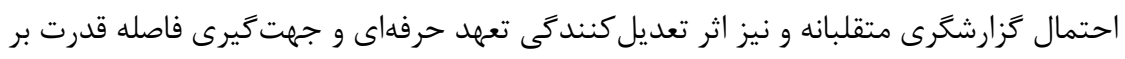

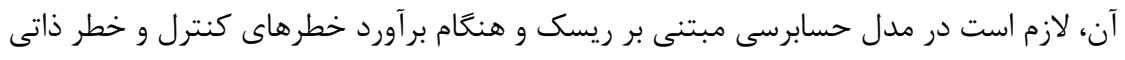
به اين عوامل توجه بيشترى شود.

V Vقدير، تشكر و ملاحظه هاى اخلاقى

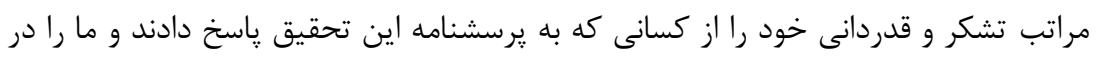

$$
\text { بسرانجام رساندنش يارى نمودند، اعلام مى داريمه }
$$

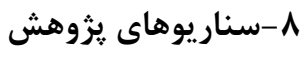

$$
\begin{aligned}
& \text { بخش اول: سوالات عمومى سوني } \\
& \text { سابقه كارى: ........سال } \\
& \square \text { زن } \\
& \text { جنسيت: مردصاص } \\
& \text { سن: }
\end{aligned}
$$

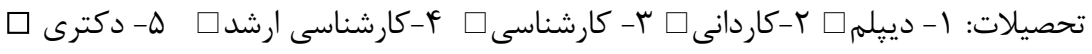

$$
\begin{aligned}
& \text { بخش دوم: سناريوها }
\end{aligned}
$$

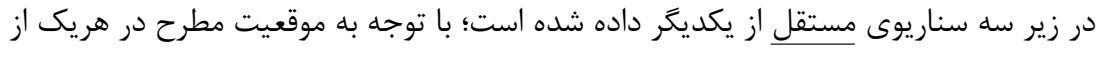

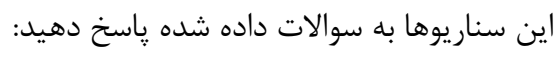

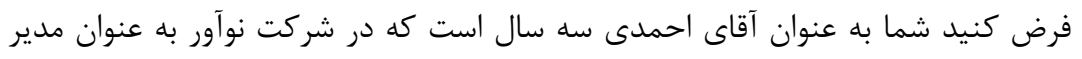

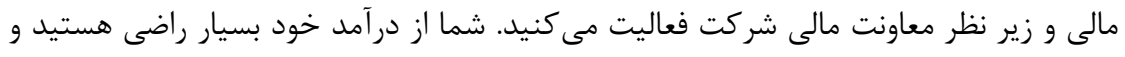

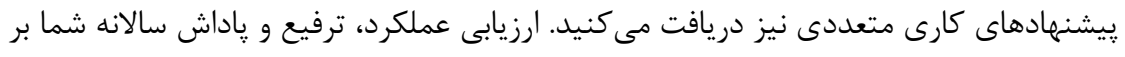

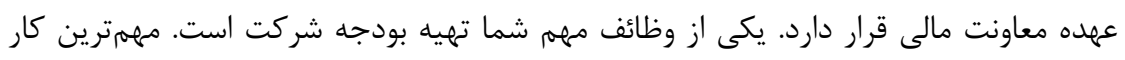


شما در تهيه بودجه، برآورد دقيق هزينه ها به ويزه هزينه سربار است. معمولاً وقتى برآورد شما از

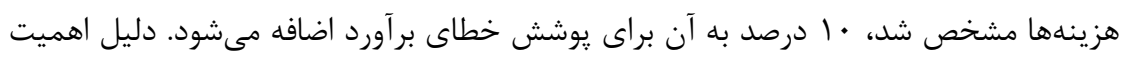

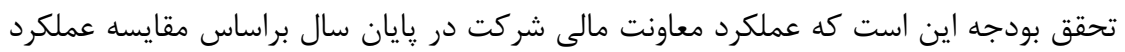

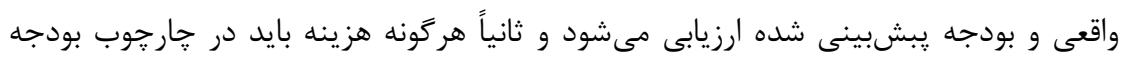

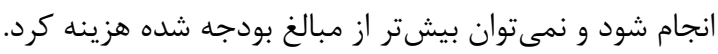

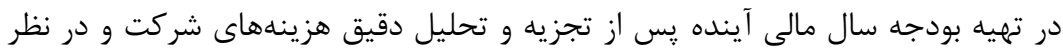

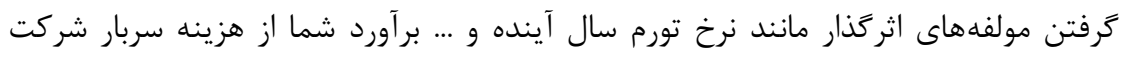

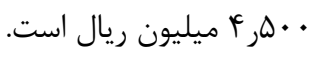
ا - هنخامى كه شما بر آورد خودتان از هزينه هاى سربار را به معاونت مالى ارائه كرديد وى بـ به شما

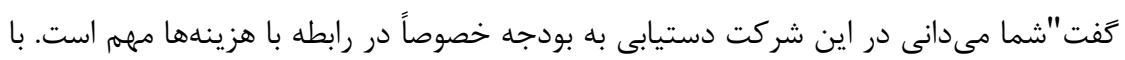

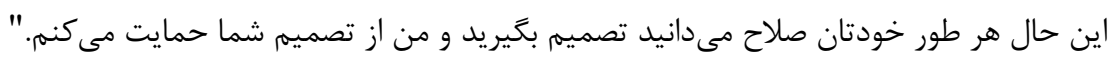

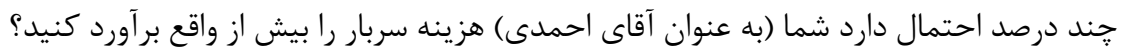

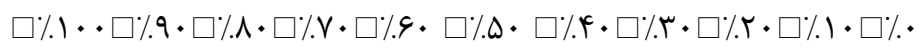

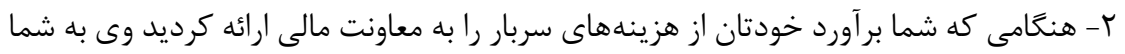

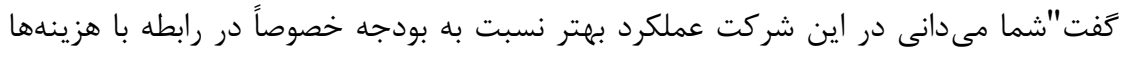

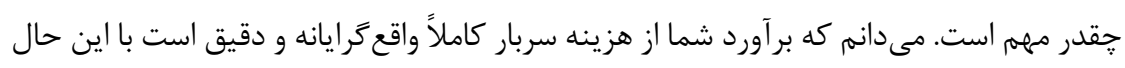

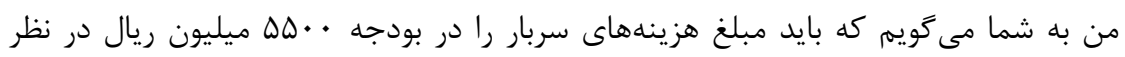

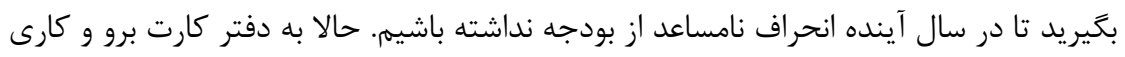

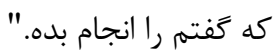

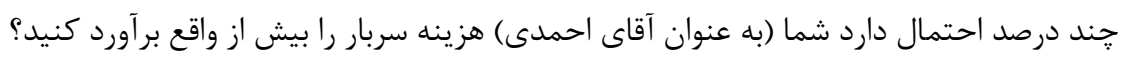

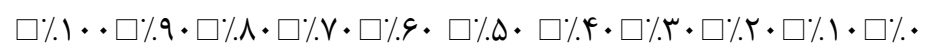

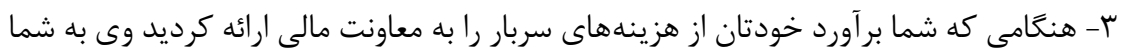

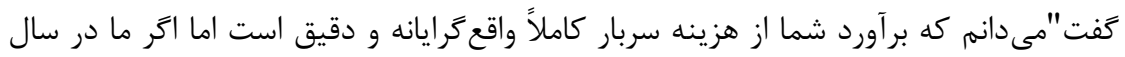

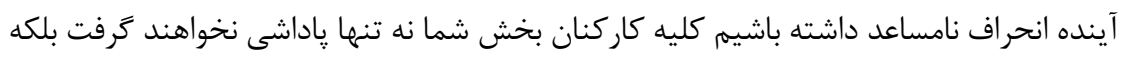

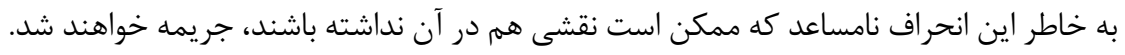

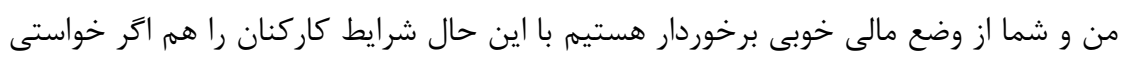

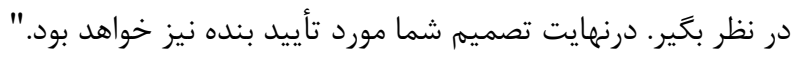

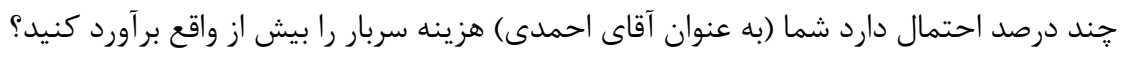

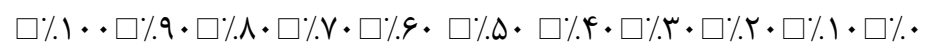


دكتر مهدوى و رضالوئى، بررسى تأثير فشارهاى همنوايى و فرمانبردارى بر تصميم تيرى غير اخلاقى...

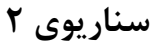

فرض كنيد شما به عنوان آقاى رضايى • اسال است كه به عنوان مدير مالى شركت آريا مشغول

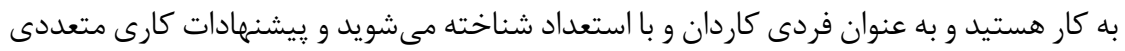
نيز داريد. شركت شما طى دو سال كذشته به واسطه ورود محصولات جديد توسط رقبا فيا بال

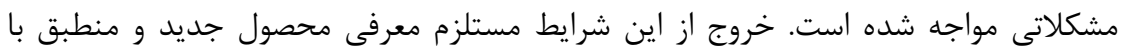

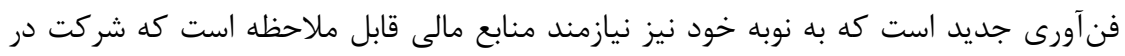
حال حاضر فاقد آن است. شما معتقد هستيد تنها راه خروج از اين شرايط اخذ تسهيلات از إن بانك

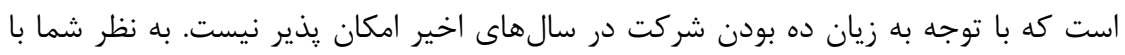

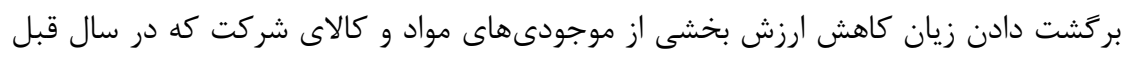

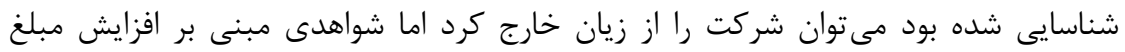

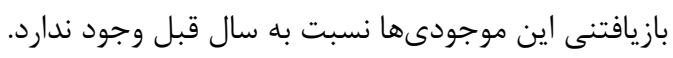

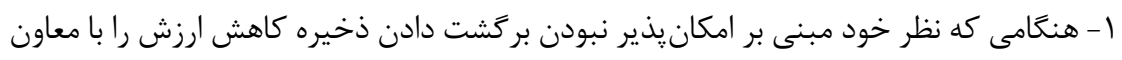

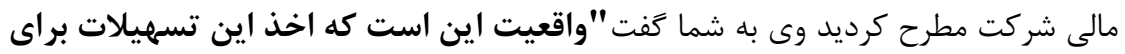
مجموعه ما ضرورى است با اين حال تصميمَيرنده نهايى در اين خصوص شما هستيد و من از تصميم شما حمايت مي كنم."

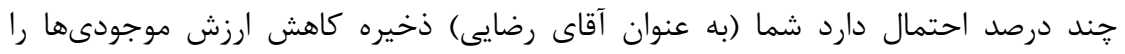
برغردانيد؟

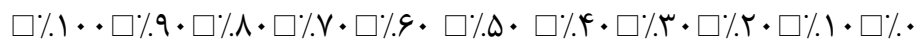

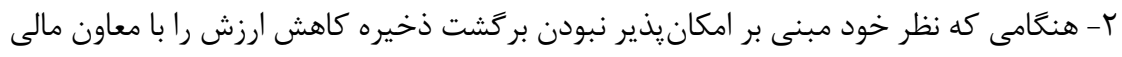

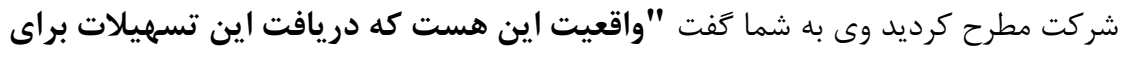

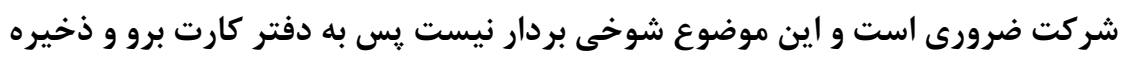
كاهش ارزش را بركردان و اتر و اما نيار. "

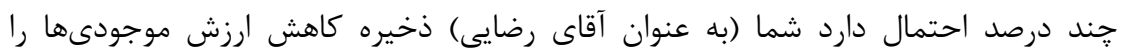
برغردانيد؟

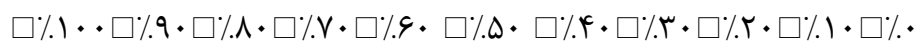

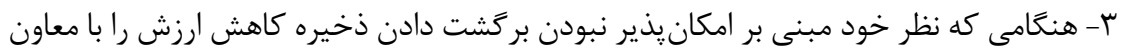

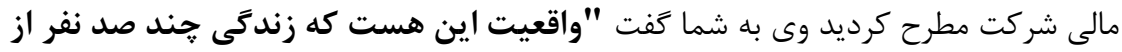

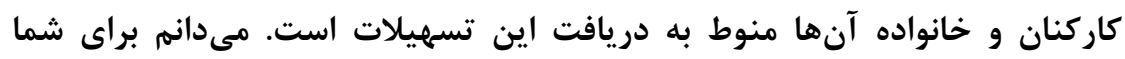


موقعيتهاى شغلى زيادى وجود دارد اما شرايط كاركنان را هم در نظر بخيريد. با اين حال من كاملاً از تصميم شما حمايت ميى رنهم."

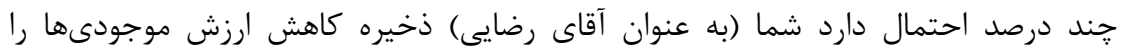
بركر دانيد؟

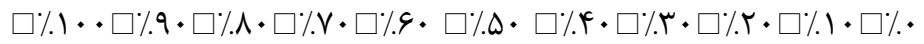

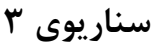
شما (به عنوان خانم محسنى) r سال است كه به عنوان رئيس حسابدارى در بخش حسابدارى

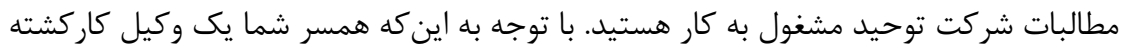
و شناخته شده است؛ از سطح رفاه مناسبى در زندكى شخصى خود برخوردار هستيد. بخش

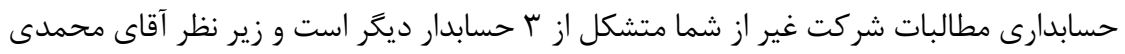

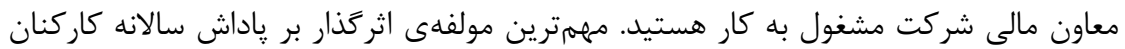

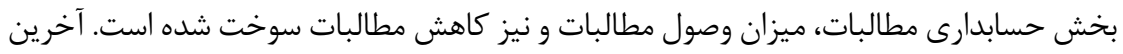

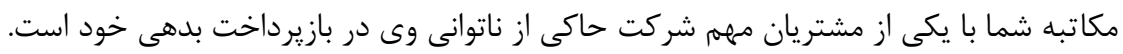

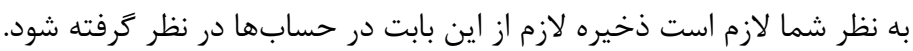

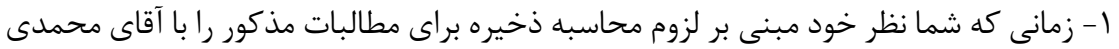

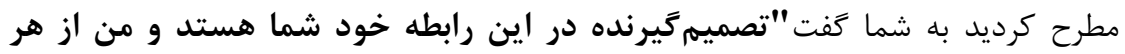
تصميمى كه شما بغير يد حمايت مى كنم."

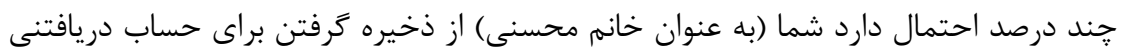
مذكور حشميوشى كنيد؟

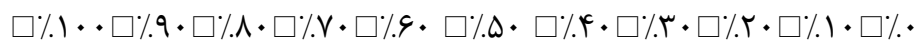

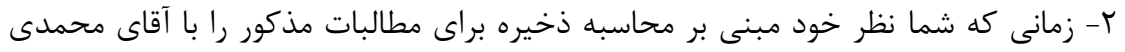

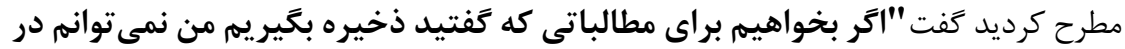
خصوص اعتبارات داده شده به مشتريان ياسخكًوى هيات مديره شركت باشم. يس اين فكر را از سرت بيرون كن ما نبايد اين ذخيره را شناسايى كنيم."

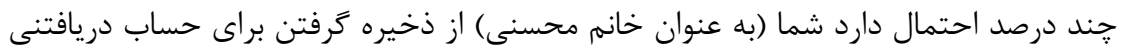
مذكور جشميوشى كنيد؟

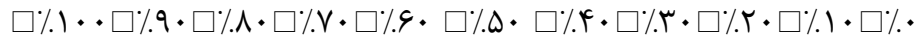
r- زمانى كه شما نظر خود مبنى بر ضرورت محاسبه ذخيره براى مطالبات مذكور را به همكاران

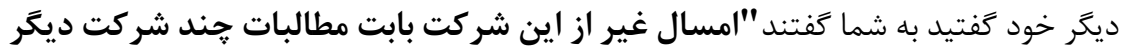




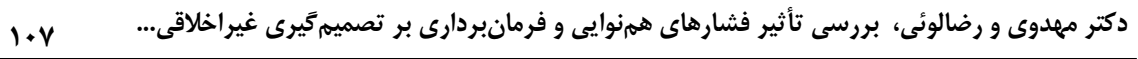

نيز ذخيره در نظر كرفتيم اكر بخواهيم اين را هم اضافه كنيم به هدفى كه براى بخش

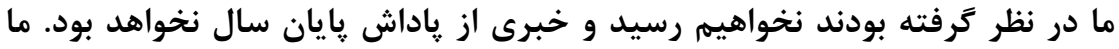

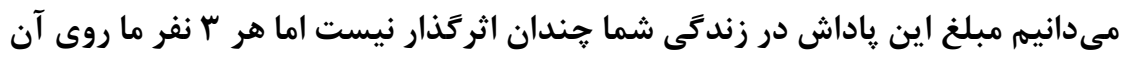

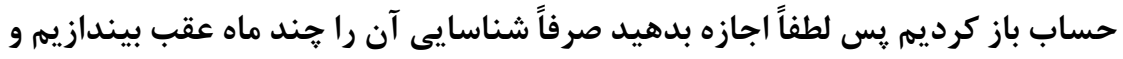

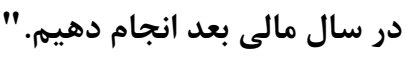

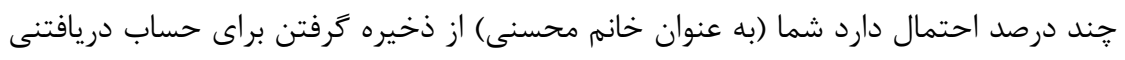
مذكور جشميوشى كنيد؟

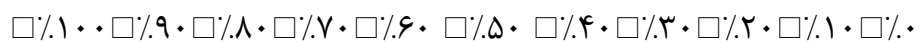

يرسشنامهها يرسشنامه جهت تيرى فاصله قدرت ميزان موافقت خود را با هر يك از ززارههاى زير بيان كنيد:

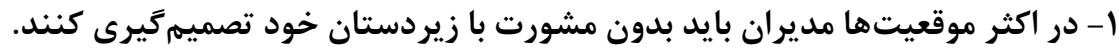

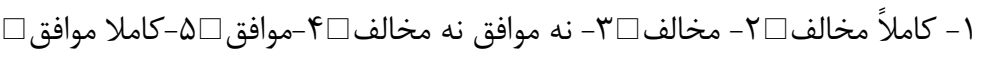
r- در رابطه با موضوعات كارى مديران حق دارند از زيردستان خود انتظار فرمانبردارى مارى داشته باشند.

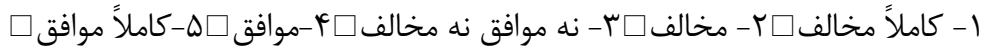

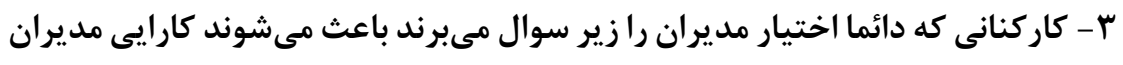
كاهش يابد.

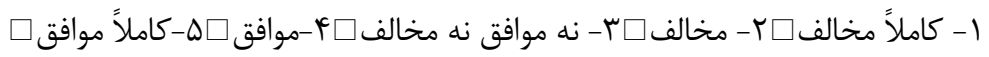

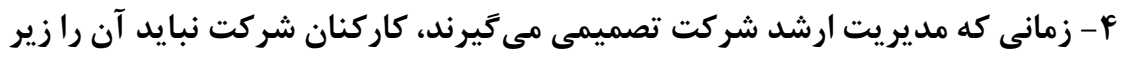

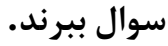

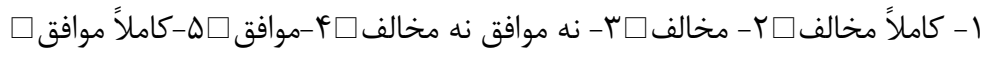

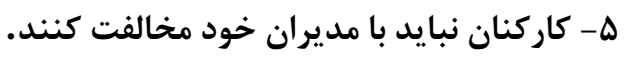

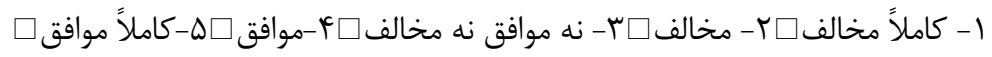

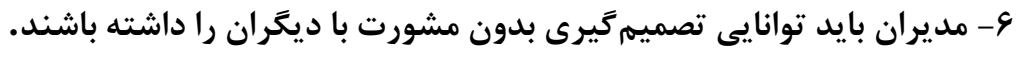

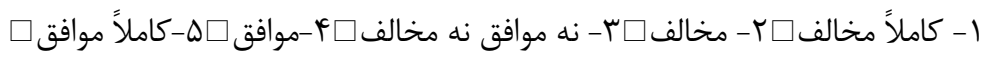

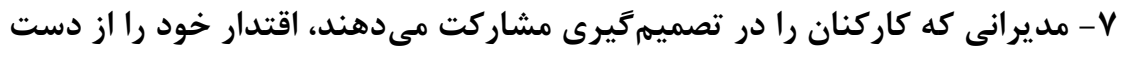


دكتر مهدوى و رضالوئى، بررسى تأثير فشارهاى همنوايى و فرمانبردارى بر تصميمكيرى غير اخلاقى...

r- ب- من حسابدار بودن را دوست ندارم.

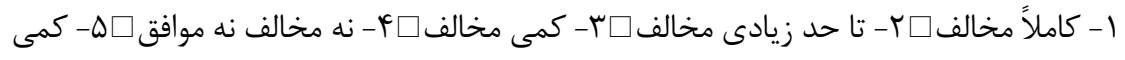

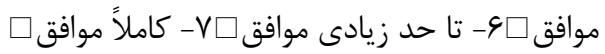

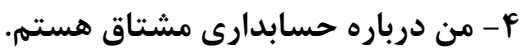

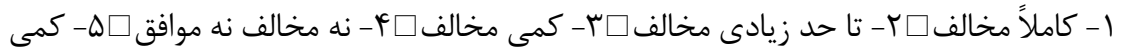

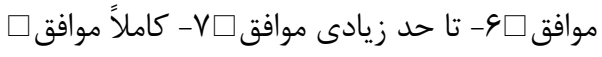

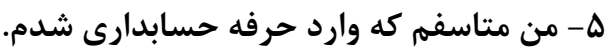

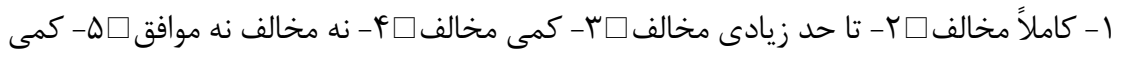

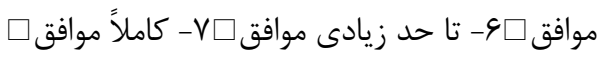
צ-من افتخار مى كنم در حرفه حسابدارى هستم.

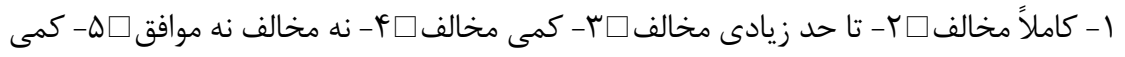

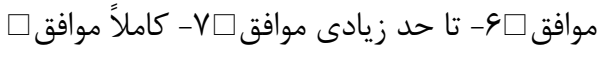

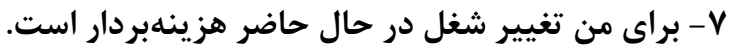

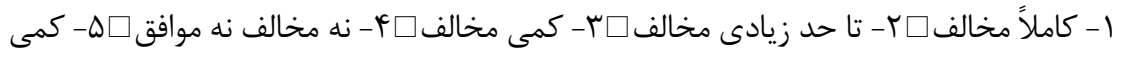

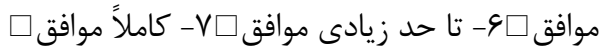

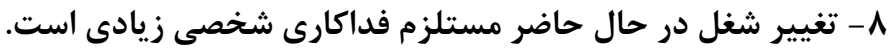

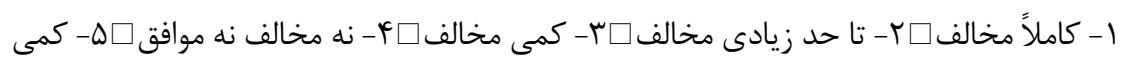

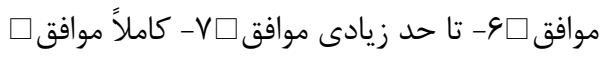

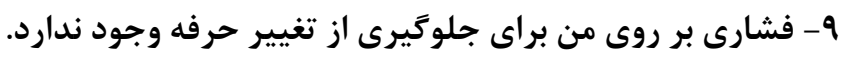

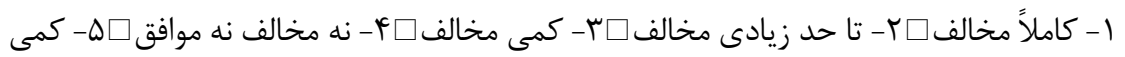

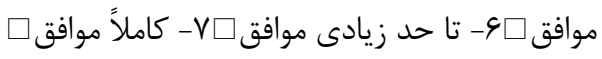

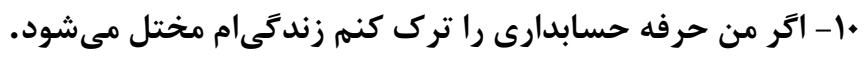

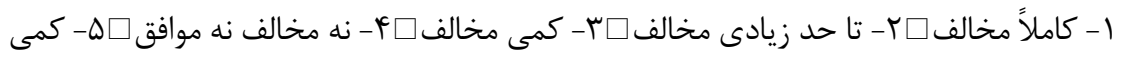

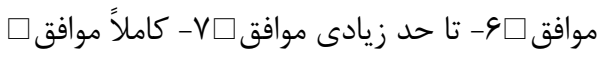

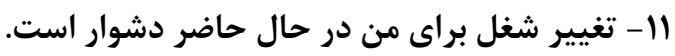

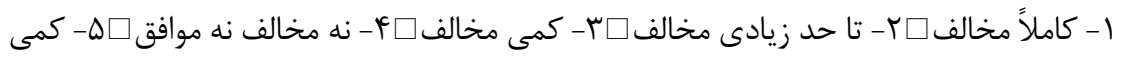

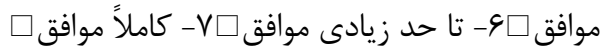
rا - من بيش از حد به حرفه حسابدارى وابسته هستهم. 


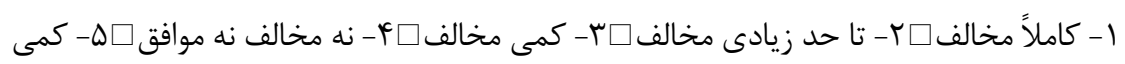

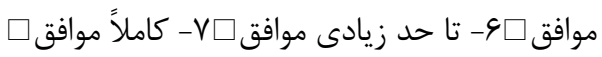

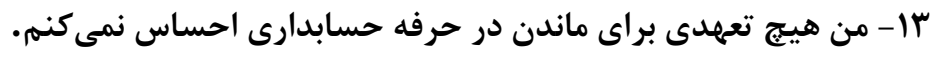

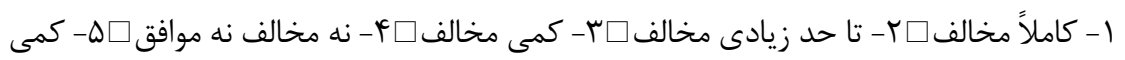

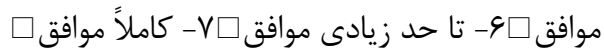

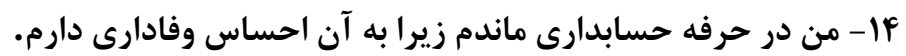

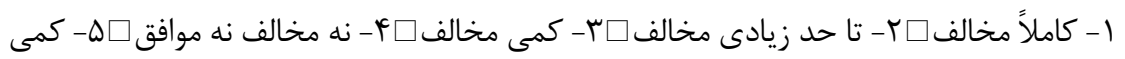

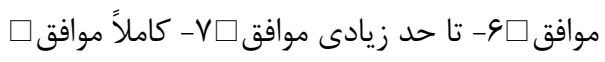

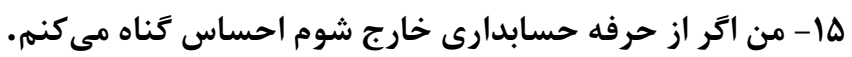

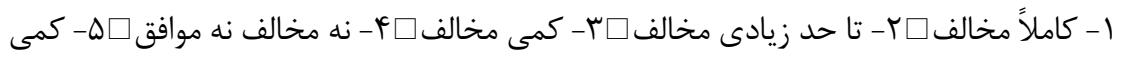

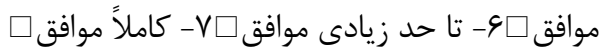

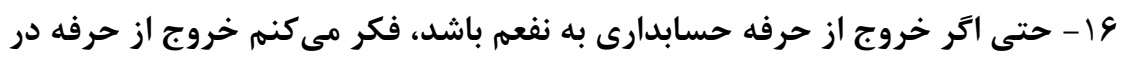
حال حاضر درست نيست.

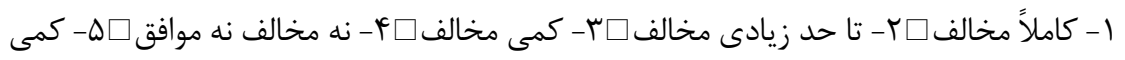

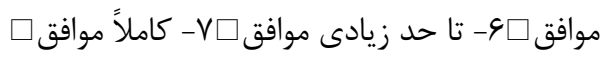

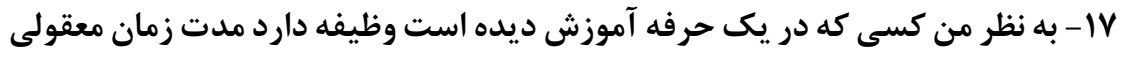
در حرفه بماند.

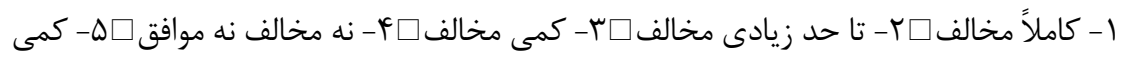

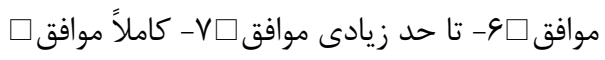
فهرست منابع

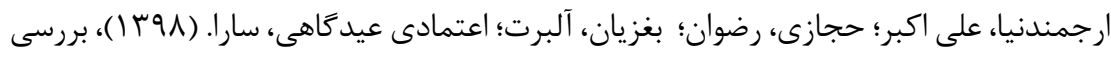

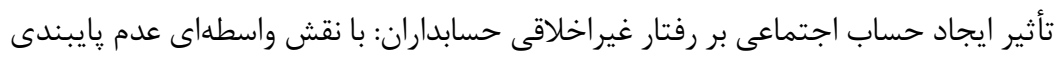

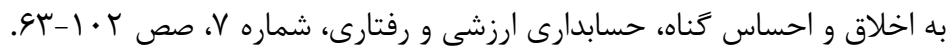

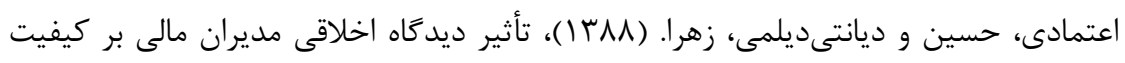

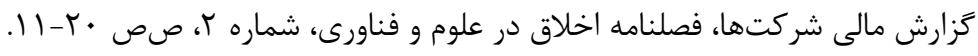

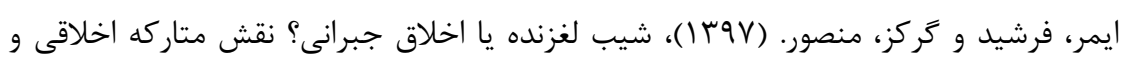

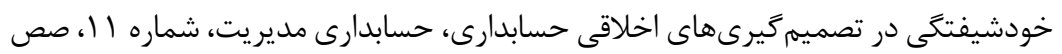


دكتر مهدوى و رضالوئى، بررسى تأثير فنارهاى همنوايى و فرمانبردارى بر تصميمتيرى غير اخلاقى...

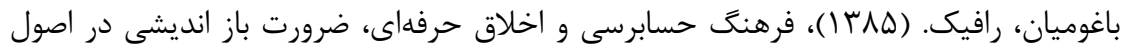

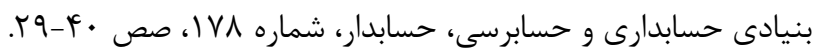

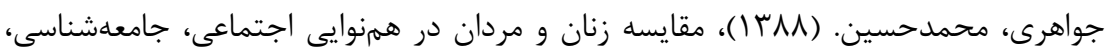

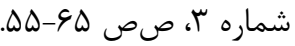

حجازى، رضوان و مصرى يور، محبوبه. (1) (1)، رابطه ضوابط اخلاق حرفهاى حسابدارى با آموزش هاى دانشخاهى، دهمين همايش ملى حسابدارى ايران.

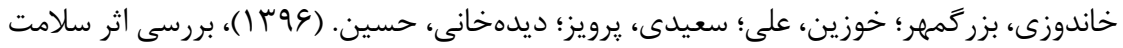

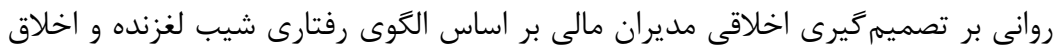

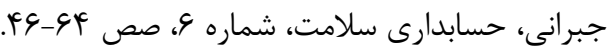

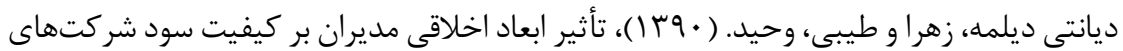

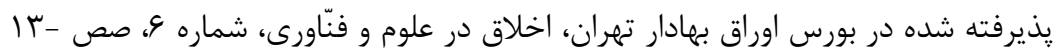

رحمانى نيا، احسان و يعقوب نزاد، احمد. (99 (1)، عوامل مؤثر بر تصميم گيرى اخلاقى حسابرسان

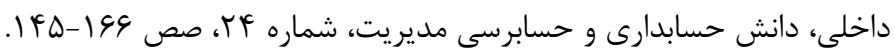

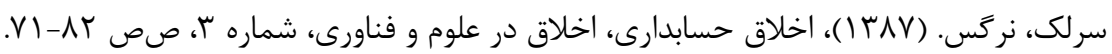

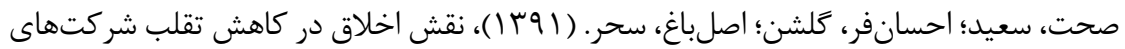

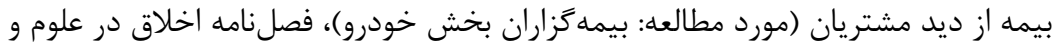

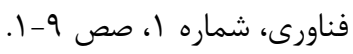

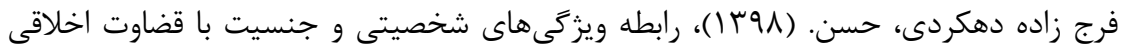

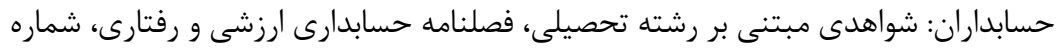

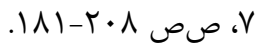
مهدوى، غلامحسين و ابراهيمى، فهيمه. (YY (1)، تأثير اخلاقيات بر تعهد سازمانى و حرفهاى

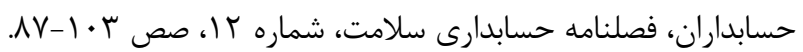

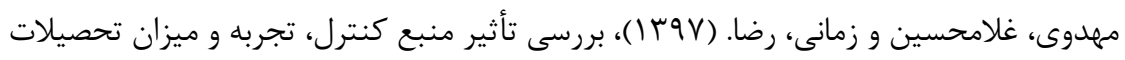

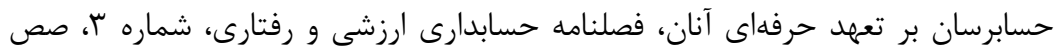
$.141-10$.

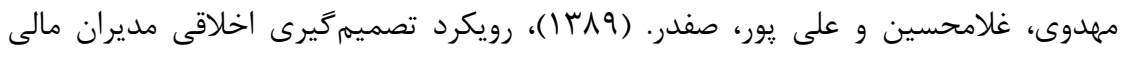

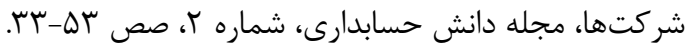




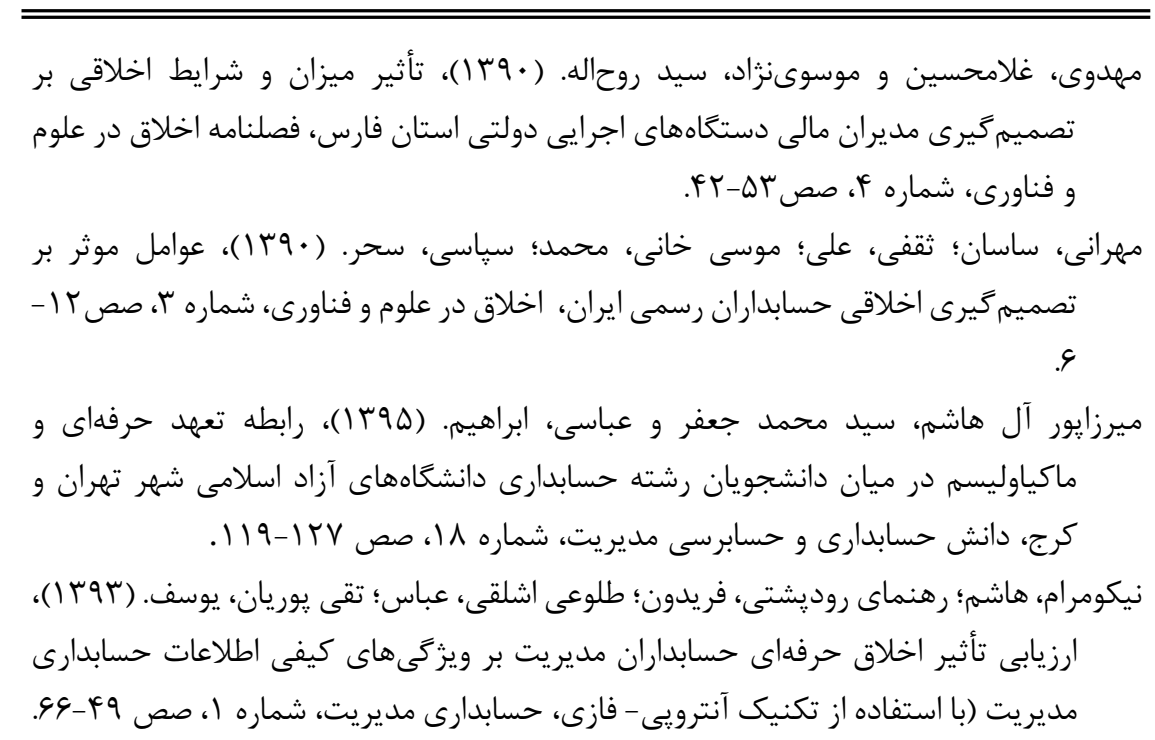

Aranya, N., and K. R. Ferris. 1984. A reexamination of accountant's organizational-professional conflict. The Accounting Review, 59(1): $1-15$.

Bakre, O. M. 2007. The unethical practices of accountants and auditors and the compromising stance of professional bodies in the corporate world: Evidence from corporate Nigeria. Accounting Forum, 31(3): 277-303.

Bandura, A. 2016. Moral disengagement: how people do harm and live with themselves. New York: Worth Publishers, Macmillan Learning.

Bishop, C. C., F. T. Dezoort, and D. R. Hermanson. 2017. The effect of CEO social influence pressure and CFO accounting experience on CFO financial reporting decisions. Auditing: A Journal of Practice \& Theory, 36(1): 21-41.

Canning, M., and B. O'Dwyer. 2003. A critique of the descriptive power of the private interest model of professional accounting ethics. Accounting, Auditing \& Accountability Journal, 16(2): 159185.

Carnegie, G. D., and C. J. Napier. 2010. Traditional accountants and business professionals: Portraying the accounting profession after Enron. Accounting, Organizations and Society, 35(3): 360-376.

Chourou, L., L. He, and L. Zhong. 2020. Does religiosity enhance the quality of management earnings forecasts? Journal of Business Finance \& Accounting.

Cialdini, R. B., and N. J. Goldstein. 2004. Social influence: Compliance and conformity. Annual Review of Psychology, 55(1): 591-621. 
دكتر مهدوى و رضالوئى، بررسى تأثير فشارهاى همنوايى و فرمانبردارى بر تصميمتيرى غيراخلاقى... س

CGMA (Chartered Global Management Accountant). 2012. Managing responsible business: A global surveyon business ethics. Available:http://www.cgma.org/resources/reports/pages/managingre sponsiblebusiness.aspx.

Clayton, B. M., and C. J. V. Staden. 2015. The impact of social influence pressure on the ethical decision making of professional accountants: Australian and New Zealand evidence. Australian Accounting Review, 25(4): 372-388.

Clugston, M., J. P. Howell, and P. W. Dorfman. 2000. Does cultural socialization predict multiple bases and foci of commitment? Journal of Management, 26(1): 5-30.

DeVellis, R. F. 2017. Scale development: Theory and applications. Newbury Park: Sage.

DeZoort, F. T., and A. T. Lord. 1997. A review and synthesis of pressure effects research in accounting. Journal of Accounting Literature, 16: $28-85$.

Dunn, P., and B. Sainty. 2019. Professionalism in accounting: a five-factor model of ethical decision-making. Social Responsibility Journal, 16(2): 255-269.

Duncan, J. R. 2001. Twenty pressures to manage earnings. CPA Journal, 71(7): 32-37.

Jackling, B., B. J. Cooper, P. Leung, and S. Dellaportas. 2007. Professional accounting bodies perceptions of ethical issues, causes of ethical failure and ethics education. Managerial Auditing Journal, 22(9): 928-944.

Khatri, N. 2009. Consequences of power distance orientation in organisations. vision: The Journal of Business Perspective, 13(1): 19.

Kirkman, B. L., G. Chen, J. L. Farh, Z. X. Chen, and K. B. Lowe. 2009. Individual power distance orientation and follower reactions to transformational leaders: A cross-level, cross-cultural examination. Academy of Management Journal, 52(4): 744-764.

Klein, G. L. 2016. Ethics in accounting: a decision-making approach. Hoboken, NJ: John Wiley \& Sons, Inc.

Lehnert, K., Y. H. Park, and N. Singh. 2015. Research note and review of the empirical ethical decision-making literature: Boundary conditions and extensions. Journal of Business Ethics, 129(1): 195-219.

Leung, P., and B. J. Cooper. 2005. Accountants, ethical issues and the corporate governance context. Australian Accounting Review, 15(35): 79-88. 
Lord, A. T., and F. T. Dezoort. 2001. The impact of commitment and moral reasoning on auditors responses to social influence pressure. Accounting, Organizations and Society, 26(3): 215-235.

Marques, P. A., and J. Azevedo-Pereira. 2008. Ethical ideology and ethical judgments in the portuguese accounting profession. Journal of Business Ethics, 86(2): 227-242.

Mintz, S. M., and R. E. Morris. 2017. Ethical obligations and decision making in accounting: Text and cases. New York, NY: McGraw-Hill Education.

Oboh, C. S. 2019. Examining the determinants of the ethical decision-making process of accounting professionals using inferential statistics. SAGE Research Methods Cases.

Parker, L. D. 1994. Professional accounting body ethics: In search of the private interest. Accounting, Organizations and Society, 19(6): 507525.

Peterson, D. K. 2003. The relationship between ethical pressure, relativistic moral beliefs and organizational commitment. Journal of Managerial Psychology, 18(6): 557-572.

Planer, D. 2019. The relationship between organizational commitment and organizational citizenship behaviors in the public and private sectors. sustainability, 11(22): 1-20.

Ponemon, L., and A. Glazer. 1990. Accounting education and ethical development: The influence of liberal learning on students and alumni in accounting practice. Issues in Accounting Education, 5(2): 195208.

Pojman, L. P. 1995. Ethical theory: Classical and contemporary readings (2nd ed.). Belmont, CA: Wadsworth Publications.

Rest, J. R. 1986. Moral development: Advances in research and theory. New York, NY: Praeger.

Snoeyenbos, M., R. F. Almeder, and J. M. Humber. 2001. Business ethics. Amherst, NY: Prometheus Books.

Stedham, Y., and R. I. Beekun. 2013. Ethical judgment in business: culture and differential perceptions of justice among Italians and Germans. Business Ethics: A European Review, 22(2): 189-201.

Tian, Q., and D. K. Peterson. 2016. The effects of ethical pressure and power distance orientation on unethical pro-organizational behavior: The case of earnings management. Business Ethics: A European Review, 25(2): 159-171.

Turegun, N. 2018. Ethical awareness, ethical decision making, and transparency: A study on Turkish CPAs in Istanbul. Accounting from a Cross-Cultural Perspective. doi:10.5772/intechopen.76867 
دكتر مهدوى و رضالوئى، بررسى تأثير فشارهاى همنوايى و فرمانبردارى بر تصميمتيرى غيراخلاقى...

Trevino, L. K., and K. A. Nelson. 2019. Managing business ethics: Straight talk about how to do it right. United States: John Wiley \& Sons.

Umphress, E. E., J. B. Bingham, and M. S. Mitchell. 2010. Unethical behavior in the name of the company: The moderating effect of organizational identification and positive reciprocity beliefs on unethical proorganizational behavior. Journal of Applied Psychology, 95(4): 769780.

Vaske, J. J., J. Beaman, and C. C. Sponarski. 2016. Rethinking internal consistency in cronbachs Alpha. Leisure Sciences, 39(2): 163-173.

Velayutham, S. 2003. The accounting profession's code of ethics: Is it a code of ethics or a code of quality assurance? Critical Perspectives on Accounting, 14(4): 483-503.

Weisbrod, E. 2009. The role of affect and tolerance of ambiguity in ethical decision making. Advances in Accounting, 25(1): 57-63.

Wing, B., and G. Lui. 2007. Culture, implicit theories, and the attribution of morality. Behavioral Research in Accounting, 19(1): 231-246.

Zheng, P., M. J. Gray, W. Z. Zhu, and G. R. Jiang. 2014. Influence of culture on ethical decision making in psychology. Ethics \& Behavior, 24(6): $510-522$. 